\title{
REVIEW
}

\section{The POU domain: versatility in transcriptional regulation by a flexible two-in-one DNA-binding domain}

\author{
Winship Herr ${ }^{1}$ and Michele A. Cleary ${ }^{1,2}$ \\ ${ }^{1}$ Cold Spring Harbor Laboratory, Cold Spring Harbor, New York 11724 USA; ${ }^{2}$ Department of Molecular Genetics and \\ Microbiology, State University of New York at Stony Brook, Stony Brook New York 11794 USA
}

The DNA-binding domains of eukaryotic transcriptional activators play a key role in selective promoter activation by tethering activation domains to the appropriate promoters and by coordinating the assembly of specific sets of transcription factors on these promoters. How an activator binds DNA and interacts with other transcriptional regulators is profoundly influenced by the structure of its DNA-binding domain. For example, activators that carry a basic-leucine zipper DNA-binding domain are well suited to establish intricate cross-regulatory networks with other family members because they bind DNA as dimers and display differing abilities to form homodimers and heterodimers with other leucine zipper proteins (for review, see Alber 1992).

Another DNA-binding domain whose structure has an impact on the transcriptional regulatory properties of activators is the POU domain. The POU (for Pit, Oct, UNC) domain was discovered as a large region of sequence similarity among three mammalian transcription factors, Pit-1, Oct-1, and Oct-2, and a nematode cell lineage gene product, UNC-86 (Herr et al. 1988). POU domains have since been identified in over 20 other metazoan proteins, although they have yet to be identified in fungal or plant proteins. Studies of these POU domain-containing proteins have implicated them in the regulation of cell-specific patterns of transcription and development, properties that have been described previously in reviews by Rosenfeld (1991), Ruvkun and Finney (1991), and Verrijzer and van der Vliet (1993).

The structure of the POU domain is unique among DNA-binding domains because it contains two structurally independent domains that cooperate functionally as a DNA-binding unit. In this review we focus on the relationship between the structure of the POU domain and the transcriptional regulatory properties of POU proteins. We first describe the structure of the Oct-1 POU domain and then discuss how the structural flexibility of the bipartite POU domain leads to flexible interactions with DNA and other proteins and, thus, functional versatility in transcriptional regulation.

\section{The POU domain}

Figure 1 shows a simple schematic of the POU domain. Two segments of the POU-domain sequence are highly conserved, an $\sim 75$-amino-acid amino-terminal POUspecific $\left(\mathrm{POU}_{\mathrm{S}}\right)$ domain and a 60 -amino-acid carboxy-terminal homeo $\left(\mathrm{POU}_{\mathrm{H}}\right.$ ) domain (Herr et al. 1988). Joining these two segments is a hypervariable linker segment that can vary from 15 to 56 amino acids in length (Herr et al. 1988; Greenstein et al. 1994).

Contrary to what the name might suggest, the POU domain is not a single structural domain; indeed, the $\mathrm{POU}_{\mathrm{S}}$ and $\mathrm{POU}_{\mathrm{H}}$ segments form separate structurally independent domains (Botfield et al. 1992). The POU and $\mathrm{POU}_{\mathrm{H}}$ domains are, however, always found together and have therefore coevolved. Thus, the POU domain, albeit not a single structural domain, is a functional unit, and therefore the term "POU domain" remains useful.

Soon after its discovery, the nature of the POU-domain structure was surmised from mutational studies, which indicated that the $\mathrm{POU}_{\mathrm{S}}$ and $\mathrm{POU}_{\mathrm{H}}$ regions form two DNA-binding subsegments and that the hypervariable region forms a flexible linker (Sturm and Herr 1988; Ingraham et al. 1990; Kristie and Sharp 1990; Verrijzer et al. 1990). Subsequent structural and biochemical studies showed that both the $\mathrm{POU}_{\mathrm{S}}$ and $\mathrm{POU}_{\mathrm{H}}$ segments have independent structures (Botfield et al. 1992) and make sequence-specific contacts with DNA (Aurora and Herr 1992; Verrijzer et al. 1992). These conclusions have been confirmed by X-ray crystallographic studies of the Oct-1 POU domain bound to a natural high-affinity binding site, the octamer sequence ATGCAAAT in the histone H2B promoter (Klemm et al. 1994).

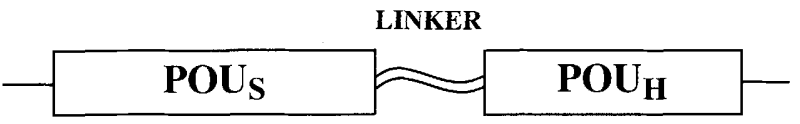

Figure 1. Linear representation of the POU domain showing the relative positions of the $\mathrm{POU}_{\mathrm{S}}, \mathrm{POU}_{\mathrm{H}}$ and linker segments. 
Figure 2 shows an illustration, adapted from Klemm et al. (1994), of the Oct-1 POU domain bound to the histone $\mathrm{H} 2 \mathrm{~B}$ octamer site. The Oct-1 $\mathrm{POU}_{\mathrm{S}}$ (red) and $\mathrm{POU}_{\mathrm{H}}$ (blue) domains both lie in the major groove, but on opposite sides of the DNA, with the $\mathrm{POU}_{\mathrm{S}}$ domain contacting the 5' ATGC segment and the $\mathrm{POU}_{\mathrm{H}}$ domain contacting to the 3' AAAT segment of the octamer sequence. Importantly, when bound to this site, the two POU subdomains make no intersubunit contacts-instead, they appear to be held together solely by the linker (gold), whose structure, if any, was not revealed by the crystallographic study (Klemm et al. 1994).

Figure 3 shows a comparison of 19 POU-domain sequences, indicating the position of $\alpha$-helices in the $\mathrm{POU}_{\mathrm{S}}$ and $\mathrm{POU}_{\mathrm{H}}$ domains and residues that are invariant among all available POU-domain sequences. Unlike the $\mathrm{POU}_{\mathrm{s}}$ domain, which is so far unique to POU proteins, homeo domains are found in many other DNA-binding proteins. Nonetheless, homeo domains found in POU proteins form a unique subfamily of more closely related homeo-domain sequences (Herr et al. 1988; Bürglin 1994; see Fig. 3). For this reason, they are referred to as $\mathrm{POU}_{\mathrm{H}}$-type homeo domains.

\section{The POU ${ }_{S}$ and $\mathrm{POU}_{\mathrm{H}}$ domains both contain} helix-turn-helix motifs

The $\mathrm{POU}_{\mathrm{H}}$ domain is nearly identical in structure to other homeo domains (Klemm et al. 1994; Sivaraja et al. 1994), whereas the Oct-1 POU $\mathrm{PO}_{\mathrm{S}}$ domain is much more similar in structure to the bacteriophage $\lambda$ and 434 repressor, and 434 Cro DNA-binding domains (Assa-Munt et al. 1993; Dekker et al. 1993). Figure 4 shows similar perspectives of the Oct-1 $\mathrm{POU}_{\mathrm{S}}$ and $\mathrm{POU}_{\mathrm{H}}$ domains bound to DNA, illustrating the similarities and differences between these two POU-domain DNA-binding structures. Both DNA-binding domains contain a helixturn-helix (HTH) motif (yellow barrels in Fig. 4), a structure common to a broad class of DNA-binding domains (for review, see Pabo and Sauer 1992). This structure consists of two approximately perpendicular $\alpha$-helices $\left(\mathrm{POU}_{\mathrm{S}}\right.$ and $\mathrm{POU}_{\mathrm{H}}$ helices $\alpha 2$ and $\alpha 3$ in Fig. 3$)$ connected by a short turn; the second of the two helices $\{\alpha 3$, the "DNA-recognition helix") makes many contacts with bases in the DNA. HTH motifs are not stable on their

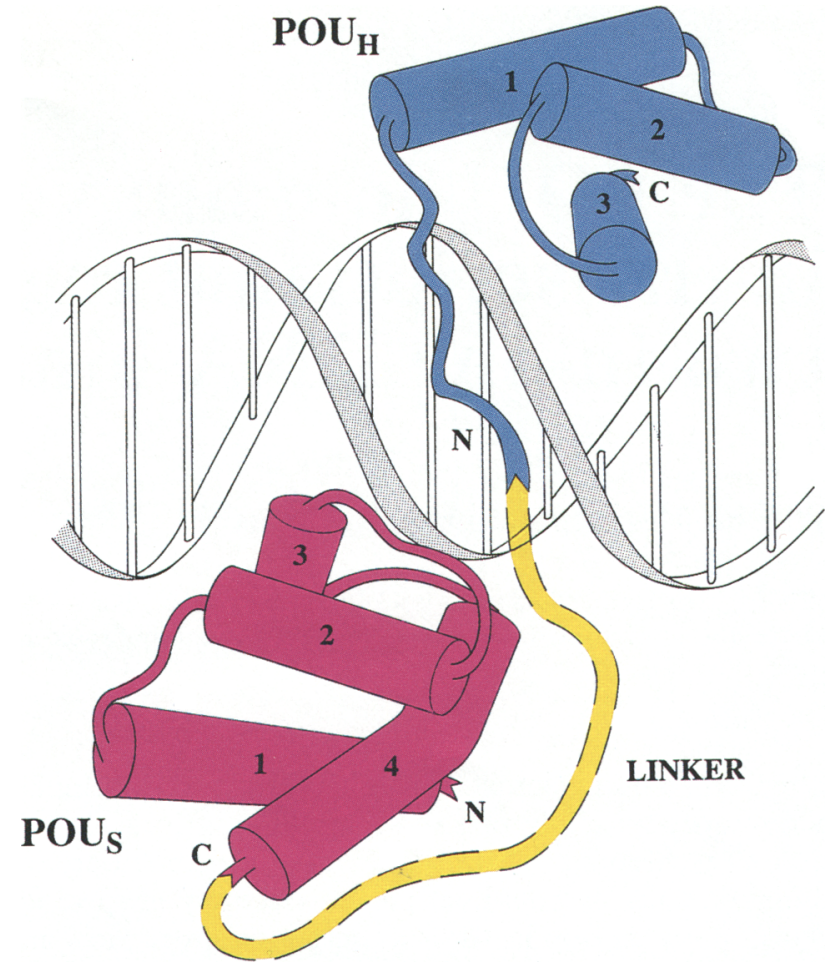

Figure 2. Schematic of the Oct-1 POU domain bound to the histone H2B octamer sequence, adapted from the X-ray cocrystal structure described by Klemm et al. (1994). The POU $\mathrm{PO}_{\mathrm{S}}$ domain is shown in red, the POU $_{\mathrm{H}}$ domain is shown in blue, and the linker segment is shown in gold, with broken lines to indicate its unknown structure. The individual $\mathrm{POU}_{\mathrm{S}^{-}}$and $\mathrm{POU}_{\mathrm{H}^{-}}$ domain helices are numbered as in Fig. 3. (N) Amino terminus; (C) carboxyl terminus.

own but gain stability through interactions with other protein segments, which can vary greatly in structure. As shown in Figure 4, in the $\mathrm{POU}_{\mathrm{S}}$ domain, as in the bacteriophage $\lambda$ repressor DNA-binding domain, two $\alpha$ helices $(\alpha 1$ and $\alpha 4)$ stabilize the HTH motif, whereas in the $\mathrm{POU}_{\mathrm{H}}$ domain, as in other homeo domains, a single $\alpha$-helix $\{\alpha 1)$ stabilizes the HTH motif.

\section{$\mathrm{POU}_{\mathrm{s}}$-domain structure}

Although the $\mathrm{POU}_{\mathrm{s}}$-domain structure is very similar to that of the $\lambda$ and 434 bacteriophage proteins, there are

Figure 3. Amino acid sequence alignment of the $\operatorname{POU}_{\mathrm{S}}(A)$, linker $(B)$, and $\operatorname{POU}_{\mathrm{H}}(C)$ segments of Oct-1 and 18 other POU domains. The sequences listed were chosen because they represent the different types of POU domains that have been identified. Sequences not included in the comparison are very similar to ones that are shown: For example, Brn-1 and Brn-4 are similar to Brn-2 (Hara et al. 1992), Bm-3.2/Brn-3b and Brn-3.1/Brn-3c are similar to Brn-3.0/Brn-3a (Gerrero et al. 1993; Theil et al. 1993), and pdm-1/dPOU19 is similar to miti-mere/pdm-2/dPOU28 (Billin et al. 1991; Lloyd and Sakonju 1991). Dots represent amino acids identical to those found in Oct-1; dashes indicate gaps introduced to maximize similarity. Invariant residues are listed below the $\mathrm{POU}_{\mathrm{S}}$ and $\mathrm{POU}_{\mathrm{H}}$ domain sequence comparisons in boldface type, and the positions of the $\alpha$-helices are indicated by boxes. The POU-domain sequences are from the following sources: Oct-1 (Sturm et al. 1988); Oct-2 (Clerc et al. 1988; Müller et al. 1988; Scheidereit et al. 1988); Skn-1 (Andersen et al. 1993a); miti-mere/pdm-2/dPOU28 (Billin et al. 1991; Lloyd and Sakonju 1991; Bhat and Schedl 1994); CEH-18 (Greenstein et al. 1994); SCIP (Monuki et al. 1989); CEH-6 (Bürglin et al. 1989); drifter/Cfla (Johnson and Hirsh 1990; Anderson et al. 1995); Brn-2 (Hara et al. 1992); Oct-3/Oct-4 (Okamoto et al. 1990, Rosner et al. 1990; Schöler et al. 1990); zfpou2 (Takeda et al. 1994); xl p25, xl p60, and xl p91 (Hinkley et al. 1992); Pit-1/GHF-1 (Bodner et al. 1988; Ingraham et al. 1988); tI-POU (Treacy et al. 1992); Brn-3.0/Brn-3a (Gerrero et al. 1993); UNC-86 (Finney et al. 1988); Brn-5 (Andersen et al. 1993b). 
A.

oct-1

Oct-2

Skn-1

miti-mere

CEH-18

SCIP

CEH -6

drifter

Brn-2

Oct $-3 / 4$

$z$ fpou 2

$\mathrm{x} 1 \mathrm{p} 25$

$x 1$ p 60

xi p91

Pit-1

tI-POU

Brn-3.0

UNC -86

Brn-5

Invariants

B.

oct -1

Oct -2

Skn-1

miti-mere

CEH-18

SCIP

CEH -6

drifter

Brn-2

Oct $-3 / 4$

$z$ fpou 2

$x 1$ p25

$x 1$ p60

$\mathrm{xl}$ p91

Pit-1

tI-POU

Brn-3.0

UNC -86

Brn-5

C.

oct-1

Oct -2

Skn-1

miti-mere

CEH-18

SCIP

CEH- 6

drifter

Brn-2

oct $-3 / 4$

zfpou 2

$\mathrm{x} 1 \mathrm{p} 25$

$x 1$ p60

$\mathrm{xl}$ p91

Pit-1

II-POU

Brn-3.0

UNC -86

Brn-5

Invariants

\section{POU-SPECIFIC DOMAINS}

EEPSDLEELEOFAKTFKORRTKLOFTQGDVGLAMCKIY $\dot{\bullet} \cdot \dot{\bullet}$

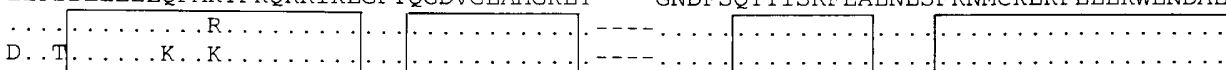

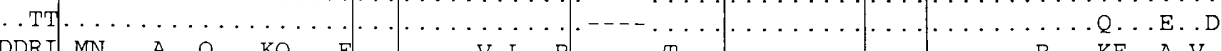

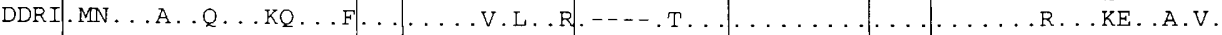

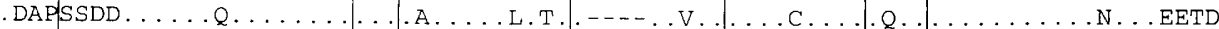

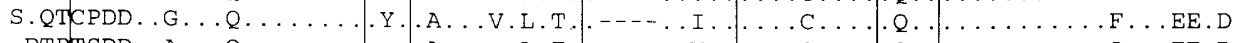

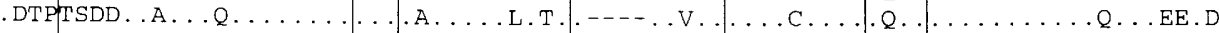

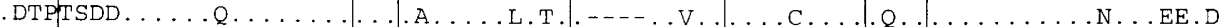

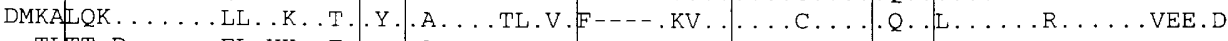

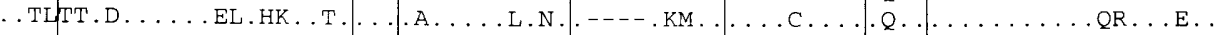

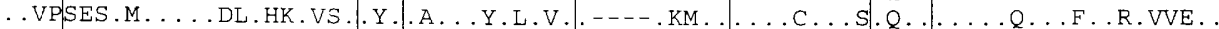

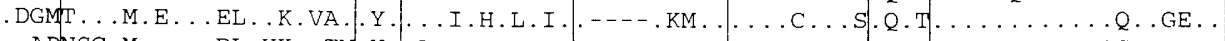

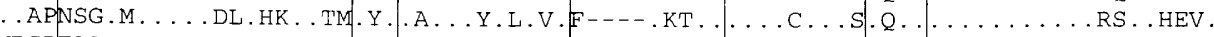

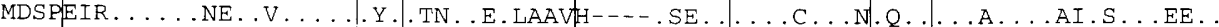

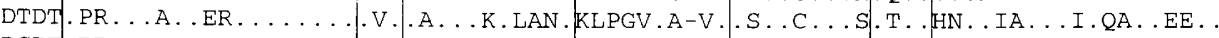

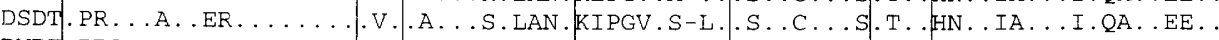

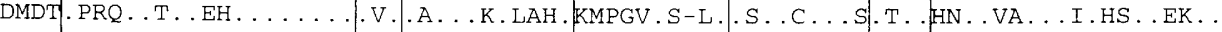

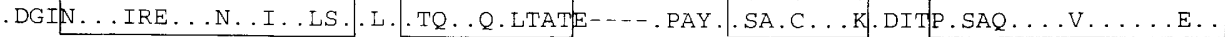
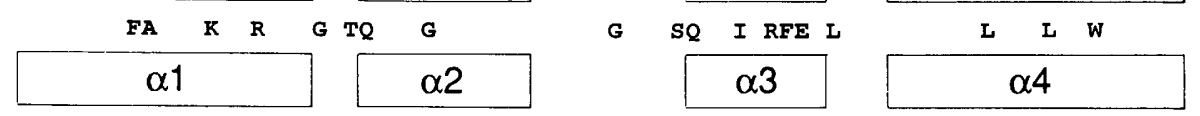

\section{POU LINKERS}

NLSSDSSLSSPSALNSPGIEGLSR TMSVDSSLPSPNQLSSPSLGFDGLPGR SSPADPSASTPSSYPTLSEVFGR

STVAKSGGGVFNINTMTSTLSSTPESILGR

MAIEGGATVTDL IDKKT I HNGNHHTIHHVDIHETSISNSISSVTASSLLSREOHVK SSSGSPTNLDKIAAQGR STTGSPNSTFEKMTGQAGR STTGSPTSIDKIAAQGR SSSGSPTSIDKIAAQGR NNENLQEICKSETLVQA NSENPQDMYKIERVFVDTR NNDNLQELINREQVIAQTR NNDNLQEMIHKAQIEEQNR NNKNLQEI ISRGQI I PQVQ QVGALYNEKVGANER AQAKNKRRDPDAPSVLPAGE GAQREKMNKPELFNGGE EAMKQKDTIGDINGILPNTD LRNQEGQQNLMEFVGGEPSK

\section{POU HOMEO DOMAINS}

1 • . 60 RRKKRTS IETNIRVALEKSFLENQKPTSEEITMIADQLNMEKEVIRVWFCNRRQKEKRIN

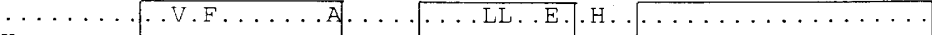

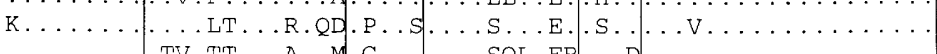

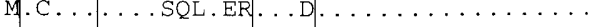
.R . . NLDM.Q.N . DTF . AL. PR. DHDKM.D . NS . ELDRD . V . . . . . . MR . VD

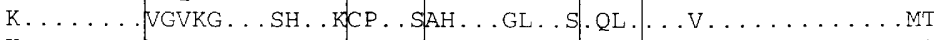

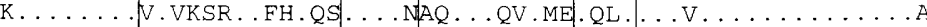

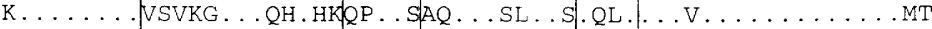
K......VVSVKG . . SH . KCP . SAQ . . SL . SI QL . . V . . . . . . . MT .KR . . . . NRV .WS . TM . KCP . SLQQ . H . N. . GL . D.V . . . . . . G. SS

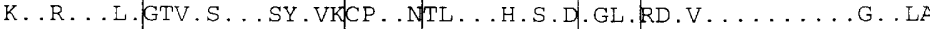
K. . R . N . NIVKGT . SY .MKCP . GAQ.MVQ . KE . .D.D.V . W W . G . QG

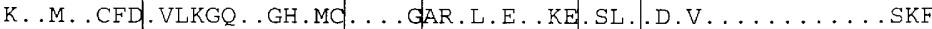
K . H . . . . N . VKCT . NY.MDCS . SAQ . AQ . RE . . . D.V . . . . . . G . . QV

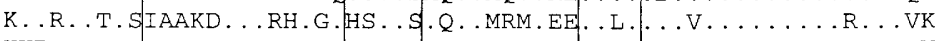
KKR . . . . AAPEKRS . AY. AVQPR. SG . K. AA . EK. DLK. N.V . . . Q Q . Q . .V

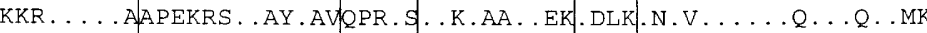

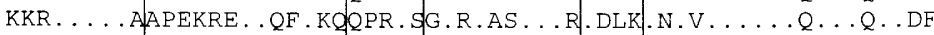
K . R . . FTPQAIE . NAY.EK. PL. GQ . . E . . KE . .YDR . V . . . . . . . TL .NTS
RT

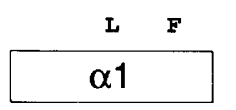

$\mathbf{P}$

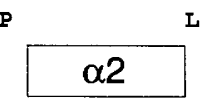

V RVWFCN RO

\section{$\alpha 3$}

Figure 3. (See facing page for legend.)

\begin{tabular}{c} 
Length \\
\hline 24 \\
27 \\
23 \\
30 \\
56 \\
17 \\
19 \\
17 \\
17 \\
17 \\
19 \\
19 \\
19 \\
19 \\
15 \\
20 \\
17 \\
20 \\
20
\end{tabular}

Species

$\mathrm{Hu}$

$\mathrm{Hu}$

$\mathrm{Mu}$

Dm

$\mathrm{Ce}$

$\mathrm{Ra}$

$\mathrm{Ce}$

$\mathrm{Dm}$

$\mathrm{Mu}$

$\mathrm{Mu}$

Zf

$\mathrm{XI}$

$\mathrm{XI}$

$\mathrm{X} 1$

$\mathrm{Ra}$

$\mathrm{Dm}$

$\mathrm{Mu}$

$\mathrm{Ce}$

$\mathrm{Ra}$ 
B.

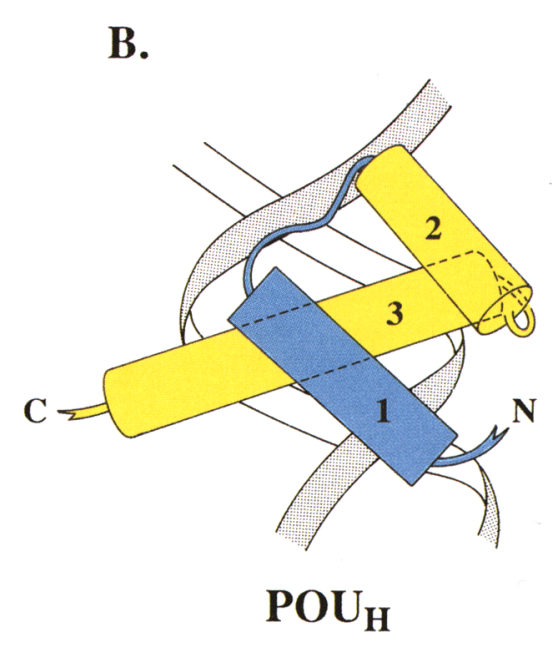

A.

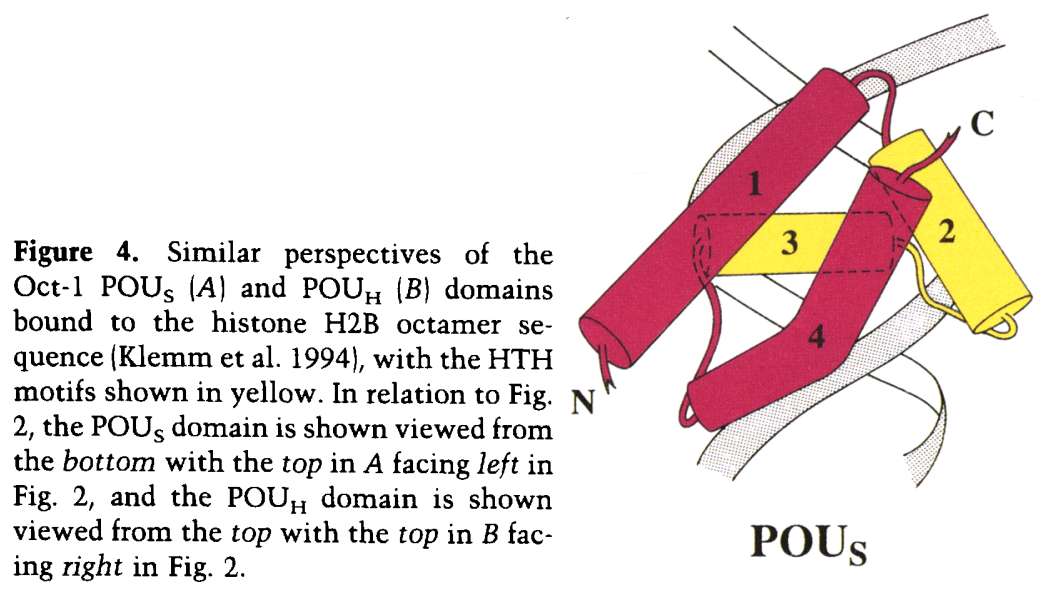

Figure 4. Similar perspectives of the Oct-1 POU $\mathrm{S}(A)$ and $\mathrm{POU}_{\mathrm{H}}(B)$ domains bound to the histone H2B octamer sequence (Klemm et al. 1994), with the HTH motifs shown in yellow. In relation to Fig. 2 , the $\mathrm{POU}_{\mathrm{S}}$ domain is shown viewed from the bottom with the top in $A$ facing left in Fig. 2, and the $\operatorname{POU}_{\mathrm{H}}$ domain is shown viewed from the top with the top in $B$ facing right in Fig. 2. differences. One significant difference is in the segment of greatest similarity among HTH-containing proteins, the HTH structure itself. Figure 5 shows a view of the Oct-1 POU $_{\mathrm{s}}$-domain HTH structure, with broken lines indicating where the $\lambda$ repressor HTH structure would

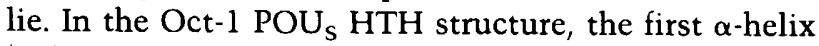
$(\alpha 2)$ is one turn longer than the corresponding $\lambda$ repressor helix, and the linker or "turn" connecting the two HTH $\alpha$-helices is also longer, maintaining the same relative positions of the two HTH $\alpha$-helices in these proteins (Assa-Munt et al. 1993; Dekker et al. 1993). The difference in HTH structure explains why, unlike in the case of the homeo domain, where the similarity to HTH-containing DNA-binding domains was deduced by sequence comparison before the structure was known (Laughon and Scott 1984; Shepherd et al. 1984), the similarity of the $\mathrm{POU}_{\mathrm{S}}$ domain to an HTH-containing DNA-binding domain was revealed only after its structure was determined (Assa-Munt et al. 1993; Dekker et al. 1993).

Because the relative positions of the two HTH $\alpha$-helices in the $\mathrm{POU}_{\mathrm{S}}$ and bacteriophage DNA-binding domains are the same, the precise positions of residues important for DNA binding (e.g., the circled amino acids in Fig. 5) are maintained. Impressively, two of these residues and their DNA interactions are the same: In both types of DNA-binding domains, the first amino acid of each $\alpha$-helix is a glutamine residue (see Fig. 3), and these residues are superimposed when the two structures are aligned (see Fig. 5) (Assa-Munt et al. 1993). In the bacteriophage (Pabo et al. 1990) and Oct-1 POU (Klemm et al. 1994) DNA-binding domains, the two glutamines make identical coordinated interactions with the phosphate backbone and an adenine base in their DNA-binding sites (the first A in the ATGCAAAT octamer sequence). Mutagenesis studies have shown that this coordinated interaction is important for DNA-sequence recognition by the bacteriophage and POU proteins (Wharton and Ptashne 1987; Li et al. 1993; Botfield et al. 1994; Jancso et al. 1994; Cleary and Herr 1995).

In the Oct-1 POU $_{\mathrm{S}}$ domain and the 434 repressor and
Cro proteins, there is an identical extended coordinated interaction among amino acid side chains involving the two glutamines and two additional amino acids, an arginine and a glutamic acid (residues 20 and 51 in Fig. 3) (Klemm et al. 1994). Other than this surprising identity, there is little sequence similarity between the $\mathrm{POU}_{\mathrm{S}}$ domain and the bacteriophage proteins. Thus, with only a low level of sequence similarity, an impressive level of structural and functional similarity between human and bacteriophage DNA-binding proteins is generated, leading to similar intramolecular and intermolecular (protein to DNA) contacts. This extraordinary similarity suggests that, because of its effectiveness for DNA binding-and possibly, as described below, for interaction with other proteins-this structure has been either maintained or derived more than once during evolution.

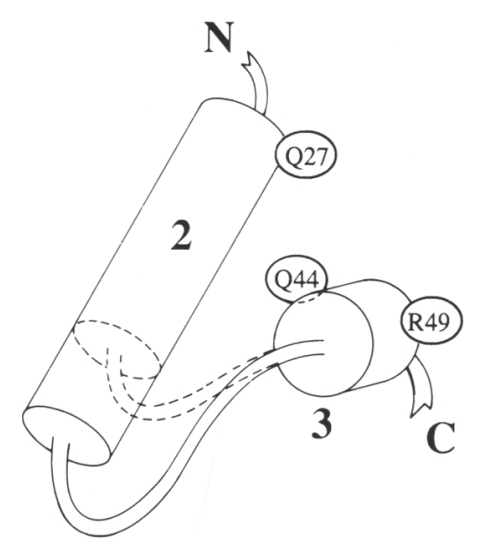

Figure 5. Comparison of the Oct-1 POU $\mathrm{PO}_{\mathrm{S}}$ and $\lambda$ repressor DNA-binding domain HTH motifs. Where the $\lambda$ repressor HTH structure differs from the $\mathrm{POU}_{\mathrm{S}} \mathrm{HTH}$ structure, the $\lambda$ repressor structure is shown with broken lines. The circled residues show the position of the Oct-1 amino acids Q27, Q44, and R49 (refer to Fig. 3). The helices are numbered 2 and 3 as in Figs. 2 and 3. (N) Amino terminus; (C) carboxyl terminus. 


\section{A $\mathrm{POU}_{\mathrm{s}}$ positive control mutation}

The similarity between the $\mathrm{POU}_{S}$ and $\lambda$ repressor DNAbinding domains extends beyond how they bind to DNA. In $\lambda$ repressor there are mutations, referred to as positive control $(p c)$ mutations, that affect its ability to activate transcription of its own gene but have little effect on its ability to bind DNA or repress transcription (Guarente et al. 1982; Hochschild et al. 1983). These $p c$ mutations lie on either the exposed surface of $\alpha$-helix 2 or the turn between $\alpha$-helices 2 and 3 of the $\lambda$ repressor HTH structure and affect direct interactions with RNA polymerase rather than with DNA (Hochschild et al. 1983; Hawley and McClure 1983; Li et al. 1994).

A $p c$-type mutation also exists in the $\mathrm{POU}_{\mathrm{S}}$ domain of the human pituitary factor Pit-1. Pit-1 (Ingraham et al. 1988), also called GHF-1 (Bodner et al. 1988), controls transcription of pituitary-specific genes, including the growth hormone and prolactin genes /see Rosenfeld 1991). Although this human Pit-1 mutant binds DNA well, it fails to activate transcription of the growth hormone gene, thus displaying a $p c$ phenotype and probably causing the human dwarfism associated with this mutation (Pfäffle et al. 1992). In parallel with the $\lambda$ repressor $p c$ mutations, the human Pit-1 $p c$ mutation maps to

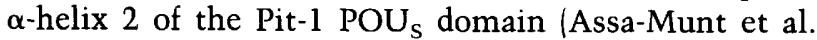
1993). Although it is unknown how Pit-1 activates transcription, the existence of these similar mutations in a human and bacteriophage protein suggests that functional as well as structural similarities are shared by these distantly related proteins.

\section{POU $_{\mathbf{H}^{-} \text {-domain structure }}$}

The conserved association of $\mathrm{POU}_{\mathrm{s}}$ domains with $\mathrm{POU}_{\mathrm{H}^{-}}$-type homeo domains suggests that there may be some advantage for the $\mathrm{POU}_{\mathrm{H}}$ domain to be part of a POU domain. As shown in Figure 3, the sequences of the DNA-recognition helix $(\alpha 3)$ in POU $_{H}$ domains are very similar to one another. For example, in contrast to other homeo domains, in all $\mathrm{POU}_{\mathrm{H}}$ domains, the ninth residue of the DNA-recognition helix is a cysteine. This position of the DNA-recognition helix is used by other types of homeo domains to discriminate among different DNAbinding sites (Hanes and Brent 1989; Treisman et al. 1989). The $\mathrm{POU}_{\mathrm{H}}$-domain cysteine residue might have been conserved at this position because it provides for a unique homeo-domain structure or contacts a DNA sequence shared by POU protein-binding sites. But, paradoxically, the Oct-1 $\mathrm{POU}_{\mathrm{H}}$ domain is essentially identi$\mathrm{cal}$ in backbone structure to other homeo domains and the conserved cysteine contacts a region that is variable even among Oct-1 binding sites-the two residues immediately $3^{\prime}$ of the octamer sequence ATGCAAAT (Klemm et al. 1994). As we propose below, the answer to this paradox may involve the difference between a homeo domain that binds independently to DNA and one like the $\mathrm{POU}_{\mathrm{H}}$ domain that binds DNA together with a second DNA-binding domain.

Unlike independent homeo domains where the DNA- binding specificity of the protein is largely conferred by the homeo domain, in POU proteins, both the $\mathrm{POU}_{\mathrm{H}}$ domain and the $\mathrm{POU}_{\mathrm{S}}$ domain confer DNA-binding specificity (Ingraham et al. 1990; Aurora and Herr 1992; Verrijzer et al. 1992; Pomerantz and Sharp 1994). Such an arrangement could result in very strict overall DNAbinding specificity if each domain were already highly specific on its own. Perhaps, in $\mathrm{POU}_{\mathrm{H}^{-}}$-type homeo domains, the DNA-recognition-helix cysteine residue has been conserved precisely because it confers little DNAbinding specificity, thus promoting more relaxed DNA sequence recognition by POU domains. Indeed, unlike the corresponding glutamine residues in the Drosophila Antennapedia and engrailed homeo domains (Kissinger et al. 1990; Otting et al. 1990), the Oct-1 $\mathrm{POU}_{\mathrm{H}}$-domain cysteine does not form a hydrogen bond with the DNA when the POU domain is bound to the histone H2B octamer site (Klemm et al. 1994); instead, it forms a hydrogen bond with a main-chain homeo-domain residue while forming van der Waals contacts with the two thymidines flanking the histone $\mathrm{H} 2 \mathrm{~B}$ octamer sequence. We imagine that, on DNA sites that provide a hydrogen bond acceptor, the cysteine could swing out to form a hydrogen bond with the DNA, adding flexibility in the way the $\mathrm{POU}_{\mathrm{H}}$ domain recognizes DNA.

\section{POU-domain linker}

The $\lambda$ repressor DNA-binding domain binds DNA as a dimer, and there is an additional $\alpha$-helix responsible for stabilizing the dimer on the DNA (see Pabo and Sauer 1992). Although the POU domain is a single molecule, it can be thought to bind DNA as a dimer-a fused heterodimer-in which the dimer subunits, the $\mathrm{POU}_{\mathrm{S}}$ and $\mathrm{POU}_{\mathrm{H}}$ domains, are stabilized through covalent attachment by a linker that takes the place of the $\lambda$ repressor dimerization helices.

Perhaps the most interesting feature of the POU domain-octamer site cocrystal structure is that, from beginning to end, the linker connecting the $\mathrm{POU}_{\mathrm{S}}$ and $\mathrm{POU}_{\mathrm{H}}$ subdomains is not visible in the electron density map (Klemm et al. 1994). Thus, the Oct-1 linker is apparently not a rigid structure. This finding explains why, as shown in Figure 3, the length and sequence of the linker can vary greatly among POU proteins. It also provides a mechanism for flexibility in how the POU domain interacts with DNA, because there might not be a strict arrangement of the $\mathrm{POU}_{\mathrm{S}}$ and $\mathrm{POU}_{\mathrm{H}}$ domains on the DNA.

Even though the linker is flexible, it can influence the DNA-binding specificity of the POU domain and in some instances is highly related between POU domains of distantly related species. The influence on DNA binding has been observed with chimeras of the Oct-1 and Pit-1 POU domains (Aurora and Herr 1992); it is not known, however, whether the effect on DNA-binding specificity observed was because of the difference in the sequence or in the length ( 24 vs. 15 amino acids) of the Oct-1 and Pit-1 linkers (see Fig. 3).

A high level of linker sequence similarity is seen when 
the Drosophila drifter and mammalian Brn-2 POU-domain linkers are compared; these proteins contain nearly identical 17-amino-acid linker sequences:

\section{Dm drifter STTGSPTS IDK IAAQGR $\mathrm{Mu} \mathrm{Brn-2}$ S SSGSPTS IDK I AAQGR}

Two other related linker segments are found in the mammalian SCIP and nematode CEH-6 proteins (see Fig. 3). Such high levels of sequence similarity suggest that, although the linker is probably flexible, at least in some cases, there are important structural features to the linker. These four proteins are all expressed in neural cells (He et al. 1989; Monuki et al. 1989; Johnson and Hirsh 1990; Hara et al. 1992; T. Bürglin and G. Ruvkun, pers. comm.). Thus, this particular linker may be conserved because it adopts a specific conformation that is important to these neural POU-domain proteins, such as one that provides for neural cell-specific interactions with DNA or with coregulatory proteins.

\section{Functional POU $\mathrm{S}_{\mathrm{S}}$ and $\mathrm{POU}_{\mathrm{H}}$ interdependence without direct protein-protein contacts}

In some cases, either as a result of alternative mRNA splicing (Day and Day 1994; Takeda et al. 1994) or mutagenesis (Greenstein et al. 1994), the $\mathrm{POU}_{\mathrm{S}}$ and $\mathrm{POU}_{\mathrm{H}}$ domains can display activity in vivo on their own. Nevertheless, the $\mathrm{POU}_{\mathrm{S}}$ and $\mathrm{POU}_{\mathrm{H}}$ domains have coevolved, and they generally cooperate in binding DNA and activating transcription. In binding DNA, they can also influence one another's DNA-binding specificity (Aurora and Herr 1992; Verrijzer et al. 1992).

Such coevolution and intersubunit influence could have been explained by direct contacts between the two DNA-bound POU subdomains that are critical for their function. It was therefore unexpected that the structure of the Oct-1 POU domain bound to an octamer site showed no evident contact between the $\mathrm{POU}_{\mathrm{S}}$ and $\mathrm{POU}_{\mathrm{H}}$ domains (Klemm et al. 1994; see Fig. 2). One hypothesis is that the $\mathrm{POU}_{\mathrm{S}}$ and $\mathrm{POU}_{\mathrm{H}}$ domains influence one another via indirect interactions through the DNA. Whatever the case, however, the lack of intersubunit contact emphasizes the importance of the linker segment for allowing these two DNA-binding modules to function interdependently as a unit.

As described below, the apparent structural flexibility of the linker allows the $\mathrm{POU}_{\mathrm{S}}$ and $\mathrm{POU}_{\mathrm{H}}$ domains to adopt diverse arrangements on the DNA, providing versatility in how POU proteins bind DNA and interact with other regulatory proteins. Before discussing such versatility, however, we first describe how POU proteins can share overlapping DNA-binding site preferences.

\section{Overlapping binding-site specificities shared by POU-domain proteins}

Consistent with their conserved structure, POU-domain proteins bind to related DNA sequences. Nonetheless, most POU-domain proteins have diverged sufficiently that their precise DNA-binding site preferences differ. Oct- 1 and Oct- 2 are an exception; they carry very closely related POU domains (see Fig. 3), and they both recognize the same precise octamer sequence found in many promoters in addition to the histone H2B promoter (Falkner and Zachau 1984; Parslow et al. 1984; Landolfi et al. 1986; Singh et al. 1986; Staudt et al. 1986). Other POU proteins also recognize the octamer sequence, but in contrast to Oct-1 and Oct-2, the octamer sequence is usually not their highest affinity binding site. For example, although Pit-1 can bind the octamer sequence, this sequence is neither its preferred binding site in vitro nor its preferred cis-regulatory site in vivo (Elsholtz et al. 1990; Aurora and Herr 19921.

Oct- 1 and Oct- 2 were named "Oct" factors because of the octamer sequence to which they bind. In some cases, other POU proteins have also been named Oct factors because they were also first identified by their ability to bind the octamer sequence [e.g., Oct-3/4 (Lenardo et al. 1989; Schöler et al. 1989), Oct-6 (SCIP) (Schöler et al. 1989), and N-Oct-3 (Brn-2) (Schreiber et al. 1990)]. In these latter cases, however, this nomenclature may be misleading because, as in the case of Pit-1, the octamer sequence may not be their preferred binding site. Such is the case for Brn-2, the mouse homolog of the human N-Oct-3 protein, which prefers sites such as those listed in Figure 6C, below (Li et al. 1993).

\section{Diverse DNA sequence recognition by POU-domain proteins}

A characteristic of POU-domain proteins is their ability to recognize diverse sets of DNA sequences. Figure 6 illustrates the diversity of sites bound by the Oct-1, Pit1 , and Brn-2 POU-domain proteins. In addition to the high-affinity octamer sequence found in many different promoters, Oct-1 and Oct- 2 recognize, although with lower affinity, important cis-regulatory sites with little octamer motif similarity (Baumruker et al. 1988; apRhys et al. 1989; Kemler et al. 1989; Bendall et al. 1993). Figure $6 \mathrm{~A}$ shows examples of two such types of sites: (OCTA $^{-}$|TAATGARAT sites, which are important for herpes simplex virus gene regulation (see below) and heptamer (Hept) sites, which are involved in immunoglobulin gene expression (Kemler et al. 1989).

Pit-1 binds a complex set of regulatory sites in the prolactin and growth hormone promoters (Bodner and Karin 1987; Nelson et al. 1988). Figure 6B shows the sequences of five high-affinity Pit-1-binding sites from these two promoters. Although a core Pit-1-binding site consensus sequence bearing similarity to an octamer sequence has been derived (see Fig. 6B), unlike Oct-1 and Oct-2, Pit-1 does not bind a highly conserved consensus sequence (Nelson et al. 1988).

The ability of POU proteins such as Oct-1 and Pit-1 to recognize diverse DNA sequences is an important aspect of their transcriptional regulatory properties. It permits variation in the incorporation of POU-domain proteinbinding sites into promoters. In addition, the binding of 


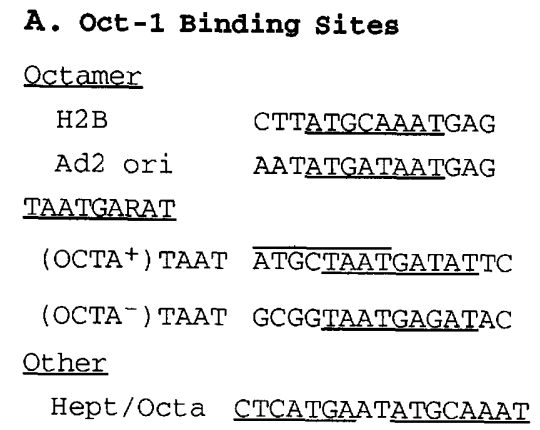

B. Pit-1 Binding Sites

rGH1 GCCATGAATAAATGATAGG

p3D ATGGTGAATAATAATGAAG

rGH2 CTGATGGATAATTTAGAAG

p1P TTCATGAATATATATATAA

p1D AAAATGCATTTTTTAATGC

Consensus ATGNATAWWT

\section{Brn-2 Binding sites \\ CRH-II TGCATAAATAATAGGC \\ CRH-IV GCGAT--TAATAAGC \\ CRH-V CACTTGGATAATAAGC}

Figure 6. DNA-binding sites of three POU-domain proteins, Oct-1, Pit-1, and Brn-2. (A) The Oct-1-binding sites are grouped according to similarity. In each case the relevant sequences are underlined except for the overlapping octamer sequence in the $\left(\mathrm{OCTA}^{+}\right)$TAATGARAT site. $(B)$ The Pit-1-binding sites and definition of a core consensus (Consensus) sequence (underlined and shown at the bottom) originate from Nelson et al. (1988). (N) Any base; (W) A or T. (C) The natural Brn-2-binding sites originate from $\mathrm{Li}$ et al. (1993) and are found in the corticotropinreleasing hormone (CRH) promoter. The $\mathrm{POU}_{\mathrm{S}}$ and $\mathrm{POU}_{\mathrm{H}}$ domain "half" sites are underlined; hyphens denote gaps placed in the sequence for better sequence alignment.

POU proteins to different DNA sequences provides selectivity in their association with regulatory cofactors.

\section{Mechanisms for flexible DNA sequence recognition by POU domains}

Studies of Oct-1 and Brn-2 have revealed two mechanisms by which POU domain proteins can recognize diverse sequences (Li et al. 1993; Cleary and Herr 1995): flexible amino acid-base interactions and flexible positioning of the $\mathrm{POU}_{\mathrm{S}}$ and $\mathrm{POU}_{\mathrm{H}}$ domains with respect to one another on the DNA.

The first mechanism involves an invariant arginine residue, R49, in the Oct-1 POU $\mathrm{S}_{\mathrm{S}}$ DNA-recognition helix (residue 49 in Fig. 3). Figure 5 shows the position of this residue relative to the position of the two glutamine residues that are shared between $\mathrm{POU}_{\mathrm{S}}$ domains and the bacteriophage $\lambda$ and 434 repressor and 434 Cro proteins. In contrast to the glutamine residue $\mathrm{Q} 44$, which makes highly selective contacts with an adenine in the DNA, R49 tolerates changes in its base contacts in the octamer site. This residue contacts the third and fourth base pairs of the ATGCAAAT octamer sequence (Klemm et al. 1994) but makes little distinction between the octamer sequence and the variant sequence ATTTAAAT, even though alanine substitution of this residue shows that it is very important for binding to both sites /Cleary and Herr 1995). These results suggest that R49 is able to modify its interactions with the DNA to permit recognition of divergent octamer sequences. An example of a natural Oct-1-binding site where this type of divergent sequence recognition may be important is in the adenovirus 2 origin of replication (Ad2 ori), where the fourth position differs from the consensus (see Fig. 6A).

Figure 7 illustrates the second more drastic mechanism for flexible DNA sequence recognition; here, the orientations and positions of the $\mathrm{POU}_{\mathrm{S}}$ and $\mathrm{POU}_{\mathrm{H}}$ domains with respect to one another can differ on the DNA. In the first example (Fig. 7A), in comparison to the Oct-1 POU domain bound to an octamer sequence (top), combined mutagenesis of the Brn-2 $\mathrm{POU}_{\mathrm{s}}$ domain and Brn-2-binding sites suggests that the orientation of the Brn-2 $\mathrm{POU}_{\mathrm{S}}$ domain is turned around by $180^{\circ}$ when bound to the variant octamer sequence GCATTAAT (bottom), in which the high-affinity POU $_{s}$ binding site ATGC is inverted (underlined; Li et al. 1993). Brn-2 (NOct-3) can also bind an octamer sequence (Schreiber et al. 1990; Li et al. 1993). On an octamer site, the Brn-2 $\mathrm{POU}_{\mathrm{S}}$ domain may switch its orientation to adopt the Oct-1 POU domain conformation (Li et al. 1993).

In the second example (Fig. $7 \mathrm{~B}$ ), the inverted Brn-2 $\mathrm{POU}_{\mathrm{S}}$ domain binds effectively to sites with different spacing between the $\mathrm{POU}_{\mathrm{S}}$ and $\mathrm{POU}_{\mathrm{H}}$ domain-binding sites ( $\mathrm{Li}$ et al. 1993). This latter mechanism explains the ability of Brn-2 to recognize the sites shown in Figure 6C, in which the spacing between the $\mathrm{POU}_{\mathrm{S}}$ and $\mathrm{POU}_{\mathrm{H}}$ domain-binding sites can vary (see underlined sequences). Another brain POU protein, Brn-3.0, has a different preference for the spacing between the $\mathrm{POU}_{\mathrm{S}}$ and $\mathrm{POU}_{\mathrm{H}}$ domain-binding sites, and this difference is dictated by a few amino acid differences in the amino-terminal region of the $\mathrm{POU}_{\mathrm{H}}$ domain (Li et al. 1993). These results elegantly demonstrate one mechanism by which different POU-domain proteins (i.e., Brn-2 and Brn-3.0) can display different DNA-binding site preferences.

Studies of Oct-1 binding to sites that respond to the herpes simplex virus (HSV) activator VP16 suggest a third rearrangement of the two POU DNA-binding domains on DNA (Fig. 7C). After HSV infection, VP16 activates HSV immediate-early (IE) transcription by forming a multiprotein VP16-induced complex with Oct-1 on sites that conform to a sequence motif called TAATGARAT, where $R$ designates a purine. TAATGARAT sites fall into two classes: $\left(\mathrm{OCTA}^{+}\right)$and $\left(\mathrm{OCTA}^{-}\right)$. As shown in Figure 6A, (OCTA ${ }^{+}$|TAATGARAT sites contain an overlapping octamer sequence (overlined), which serves as a binding site for Oct-1 (Kristie et al. 1989), whereas |OCTA ${ }^{-}$|TAATGARAT sites bear little octamer similarity but still bind Oct-1, albeit with reduced affinity 
A.

Orientation
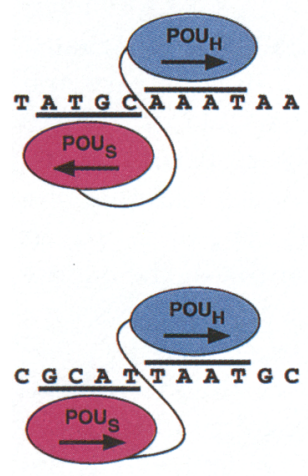

Oct-1 vs. Brn-2
B.

Spacing
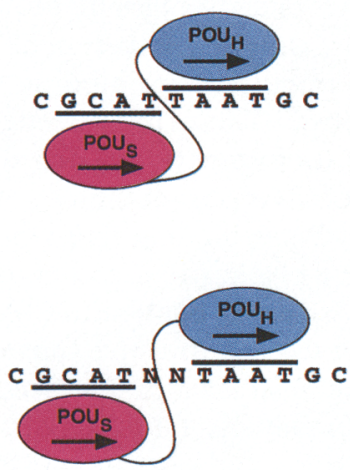

Brn-2 c.

Positioning
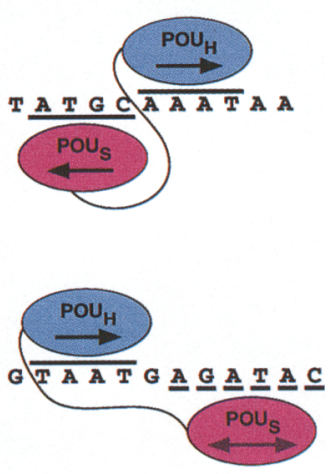

Oct-1
Figure 7. Different arrangements of the

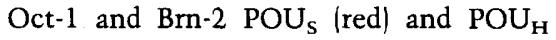
(blue) domains on DNA. POU $\mathrm{S}_{\mathrm{S}}$ and $\mathrm{POU}_{\mathrm{H}}$ domain-binding sites are underlined and overlined, respectively. Arrows indicate the orientation of the $\mathrm{POU}_{\mathrm{S}}$ and $\mathrm{POU}_{\mathrm{H}}$ domains based on the direction of the turn between $\alpha$-helices 1 and 2 in each structure (i.e., pointing up in Fig. 4). (A) Oct-1 bound to an octamer sequence (top) and Brn-2 bound to a consensus Brn-2 DNAbinding site with a spacing of zero between half sites (bottom) are shown. $(B)$ Brn-2 bound to consensus sites with a spacing of 0 (top) or 2 (bottom) bp between $\mathrm{POU}_{\mathrm{S}}$ and $\mathrm{POU}_{\mathrm{H}}$ domain-binding sites. (N) Any base. $(C)$ Oct-1 bound to octamer (top) and (OCTA ${ }^{-}$|TAATGARAT (bottom) sites. The broken underline and double-headed arrow indicate the ambiguity in orientation of the $\mathrm{POU}_{\mathrm{S}}$ domain over the GARAT (GAGATAC) element.
(Baumruker et al. 1988; apRhys et al. 1989). On the (OCTA ${ }^{-}$|TAATGARAT site (Fig. 7C, bottom), combined POU domain and binding site mutagenesis experiments suggest that the $\mathrm{POU}_{\mathrm{S}}$ domain is positioned over the GARAT element to the side opposite of the $\mathrm{POU}_{\mathrm{H}}$ domain from where it is located on an octamer site /Fig. 7C, top/ (Cleary and Herr 1995). The orientation of the $\mathrm{POU}_{\mathrm{S}}$ domain on the (OCTA ${ }^{-}$)TAATGARAT site, however, is not known (hence the double-headed arrow in the Fig. $7 \mathrm{Cl}$; indeed, the $\mathrm{POU}_{\mathrm{S}}$ domain may be able to bind in either orientation.

These results suggest that on VP16-responsive $\left(\mathrm{OCTA}^{+}\right)$and $\left(\mathrm{OCTA}^{-}\right)$TAATGARAT sites the Oct- 1 $\mathrm{POU}_{\mathrm{S}}$ and $\mathrm{POU}_{\mathrm{H}}$ domains are positioned differently. On an OCTA $^{+}$|TAATGARAT site, however, the POU $_{\mathrm{S}}$ domain may be able to bind to either the 5' ATGC segment of the octamer sequence as in Figure 7C, top, or to the 3' GARAT segment as in Figure 7C, bottom. This flexibility may explain the conformational alteration in Oct-1 binding observed by Walker et al. (1994) on (OCTA $^{+} \mid$TAATGARAT sites containing wild-type versus mutated GARAT segments. They found that, when the $3^{\prime}$ GARAT segment is mutated, the Oct-1 POU domain binds the 5' ATGC octamer segment more effectively. The models for Oct-1 binding to the octamer and TAATGARAT sequences in Figure $7 \mathrm{C}$ suggest that the

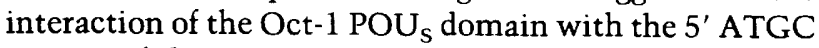
portion of the octamer sequence should be stabilized by

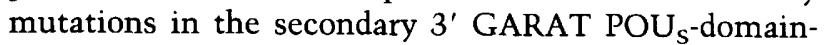
binding site.

The three different modes of flexible POU domain interaction with DNA illustrated in Figure 7 appear to arise from the unique property of POU domains: that they are made up of the tethering of two structurally independent DNA-binding domains through a flexible linker. It should be cautioned, however, that all of the studies that have suggested flexible interactions with
DNA have been indirect, generally involving analyses of the differential effects of combined POU-domain and binding-site mutations on POU-domain-DNA binding; direct studies, such as protein-DNA cross-linking or $\mathrm{X}$-ray crystallography, will be necessary to establish the veracity of these conclusions.

\section{Modulation of POU-domain DNA-binding specificity by post-translational modification}

The DNA-binding activity of POU domains can be influenced by post-translational modification. Phosphorylation of homologous sites in the Oct-1 and Pit-1 POU domains by protein kinase A can inhibit DNA binding (Kapiloff et al. 1991; Segil et al. 1991). In Oct-1, such modification occurs during mitosis and inhibits binding to the histone H2B octamer site (Segil et al. 1991). In Pit-1, by comparing the binding of nonphosphorylated and phosphorylated Pit-1 to a series of different Pit-1binding sites, Kapiloff et al. (1991) showed that protein kinase A phosphorylation modulates its DNA-binding activity, having little if any effect on binding to some sites and drastically reducing binding to other sites. Thus, phosphorylation provides an elegant mechanism to modulate POU-domain DNA-binding activity in response to cellular changes such as during the cell cycle or in response to extracellular signals.

\section{Cooperative binding among POU proteins to cis-regulatory sites}

One of the distinctive modes of DNA-binding versatility exhibited by POU proteins is their ability to bind DNA either as a monomer or cooperatively as a homo- or hetero-POU-domain dimer. Oct-1 and Oct- 2 bind cis-regulatory sites effectively as monomers, whereas Pit-1 forms highly cooperative homodimeric complexes on its 
regulatory sites (Ingraham et al. 1990). Pit-1 and Oct-1 can also form a heterodimeric complex on a Pit-1-binding site in the prolactin promoter (site plP in Fig. 6B) (Voss et al. 1991). This heterodimeric complex displays somewhat higher levels of transcriptional activation than either protein alone, indicating transcriptional activation synergy between these two POU proteins (Voss et al. 1991).

Oct-1 and Oct-2 form cooperative homo- or heterodimers on a regulatory site in immunoglobulin heavy-chain (IgH) promoters (Kemler et al. 1989; LeBowitz et al. 1989; Poellinger et al. 1989). This site contains two adjacent Oct-1- or Oct-2-binding sites, a high-affinity octamer sequence, and the much lower affinity heptamer sequence (see the Hept/Octa site in Fig. 6A). Although of low affinity for Oct-1 or Oct- 2 on its own, in cooperation with the octamer sequence, the heptamer sequence can contribute to activation of transcription in vivo (Kemler et al. 1989).

The arrangement of the $\mathrm{POU}_{\mathrm{S}}$ and $\mathrm{POU}_{\mathrm{H}}$ domains in these natural dimeric complexes is not known. On a synthetic pair of inverted octamer sites, cooperativity is probably achieved through interactions between adjacent $\mathrm{POU}_{\mathrm{S}}$ domains (LeBowitz et al. 1989). It is possible, however, that on the natural Pit-1 and Oct-1/Oct-2 sites the two POU domains in the dimer adopt different conformations, such as the two arrangements shown in Figure $7 \mathrm{C}$. Indeed, Pit- 1 binds the two sites shown in Figure 7C, the octamer and (OCTA ${ }^{-}$|TAATGARAT sites, with near equal effectiveness as a monomer (Aurora and Herr 1992). On its more complex regulatory sites, the Pit-1 POU domain might bind as a combination of these two arrangements, thus generating a homodimer that is structurally heterodimeric. Understanding how Pit-1 binds to its natural sites will probably require elucidation of the structure of the Pit-1 POU domain bound to such a site.

\section{POU-domain interactions with heterologous proteins}

In addition to binding DNA together with other family members, POU proteins display considerable versatility in their interaction with heterologous non-POU proteins. Table 1 shows a summary of the interactions with heterologous proteins that have been described on different promoters and, in one case, on a viral origin of replication. The POU proteins Oct-1 and Oct- 2 have also been shown to interact with a heterologous protein, the TATA box-binding protein TBP, off of DNA (Zwilling et al. 1994); however, because this interaction is not dependent on cis-regulatory sites, it is difficult to demonstrate that it is used to regulate transcription by these proteins.

In Table 1, the proteins that associate with the POU proteins have been divided into three different types of transcription factors-activator, coregulator, and basal transcription factor-and a DNA replication factor, the adenovirus DNA polymerase. The basal transcription factor is the proximal sequence element (PSE)-binding factor PTF (Murphy et al. 1992; Yoon et al. 1995), which is probably related but not identical to the TBP-containing basal complex called SNAP (Sadowski et al. 1993; Henry et al. 1995). The Oct-1 and Oct-2 POU domains bind cooperatively with PTF and $\mathrm{SNAP}_{c}$, demonstrating a direct cooperative interaction between a site-specific DNA-binding domain and a basal transcription factor complex (Murphy et al. 1992; V. Mittal, M. Cleary, W. Herr, and N. Hernandez, unpubl.).

Members of the activator and coregulator classes are differentiated by their inherent ability to bind cis-regulatory sites on their own. The mammalian activators $\mathrm{Spl}, \mathrm{Ap}-1$, and progesterone (PR) and glucocorticoid (GR) receptors and the Caenorhabditis elegans activator MEC-3 bind certain regulatory DNA sites well on their own but also cooperate with a POU-domain protein in binding to sites as a heteromeric complex. In this man-

Table 1. Factors that associate with POU-domain proteins on cis-regulatory sites

\begin{tabular}{|c|c|c|c|c|}
\hline POU protein & $\begin{array}{l}\text { Interacting } \\
\text { factor }\end{array}$ & Type & $\begin{array}{l}\text { POU domain } \\
\text { responsible }\end{array}$ & Comment \\
\hline $\begin{array}{l}\text { Oct-1 } \\
\text { Oct-1 } \\
\text { Oct-1 } \\
\text { UNC-86 }\end{array}$ & $\begin{array}{l}\text { Spl } \\
\text { Ap-1 } \\
\text { PR/GR } \\
\text { MEC-3 }\end{array}$ & $\begin{array}{l}\text { activator } \\
\text { activator } \\
\text { activator } \\
\text { activator }\end{array}$ & $\begin{array}{l}\text { N.D. } \\
\text { N.D. } \\
\text { N.D. } \\
\text { yes }\end{array}$ & $\begin{array}{l}\text { zinc finger protein } \\
\text { bZIP protein } \\
\text { steroid receptors } \\
\text { homeo-domain protein }\end{array}$ \\
\hline $\begin{array}{l}\text { Oct-1 } \\
\text { Oct-3/4 } \\
\text { Oct- } 1 \text { and Oct- } 2\end{array}$ & $\begin{array}{l}\text { VP16 } \\
\text { E1A } \\
\text { OCA-B/OBF-1/Bobl }\end{array}$ & $\begin{array}{l}\text { coregulator } \\
\text { coregulator } \\
\text { coregulator }\end{array}$ & $\begin{array}{l}\text { yes }\left(\mathrm{POU}_{\mathrm{H}}\right) \\
\text { N.D. } \\
\text { yes }\end{array}$ & $\begin{array}{l}\text { herpesvirus protein } \\
\text { adenovirus protein } \\
\text { B-cell-specific protein }\end{array}$ \\
\hline Oct-1 & PTF $\left(\mathrm{SNAP}_{\mathrm{c}}\right)$ & basal factor & yes & snRNA promoter factor \\
\hline Oct-1 & Ad DNA pol & replication factor & yes $\left(\mathrm{POU}_{\mathrm{H}}\right)$ & adenovirus protein \\
\hline
\end{tabular}

References for each interaction: Oct-1 with Spl (Janson and Pettersson 1990); Oct-1 with Ap-1 (Ullman et al. 1991, 1993); Oct-1 with PR and GR (Brüggemeier et al. 1991); UNC-86 with MEC-3 (Xue et al. 1993); Oct-1 with VP16 (see text); Oct-3/4 with EIA (Schöler et al. 1991); Oct-1 and Oct-2 with OCA-B/OBF-1/Bob1 (Luo et al. 1992; Gstaiger et al. 1995; Luo and Roeder 1995; Strubin et al. 1995); Oct-1 with PTF (SNAP $)$ (Murphy et al. 1992; V. Mittal, M. Cleary, W. Herr, and N. Hernandez, unpubl.); Oct-1 with Ad DNA pol (Coenjaerts et al. 1994).

Abbreviations: (PR) Progesterone receptor; (GR) glucocorticoid receptor; (N.D.) not determined. 
ner, Oct- 1 interacts with (1) the TFIIIA zinc finger protein Spl in small nuclear RNA (snRNA)-type transcription (Janson and Pettersson 1990), (2) bZIP proteins in the Ap-1 (OAP) transcription complex in binding to the interleukin-2 promoter (Ullman et al. 1991, 1993), and (3) the steroid receptors PR and GR in binding to the murine mammary tumor virus (MMTV) promoter (Brüggemeier et al. 1991). Furthermore, UNC-86 cooperates with the homeo-domain protein MEC-3 in binding to the mec-3 promoter (Xue et al. 1993).

The coregulators listed in Table 1 do not bind DNA effectively on their own but can do so in association with a POU-domain protein and can have profound effects on the regulatory properties of POU-domain proteins. These coregulators include two viral proteins, the HSV virion protein VP16 and the adenovirus protein E1A, and a B-cell coregulator variously termed OCA-B, OBF-1, and Bobl. The best understood of these coregulator-POUdomain interactions is the selective association of VP16 with the Oct-1 but not the Oct-2 POU domain in a VP16induced complex formed after HSV infection on IE promoters.

\section{The VP16-induced complex}

Figure 8 shows a diagram of the VP16-induced complex; its protein components include VP16, Oct-1, and a second host cell factor that we refer to as HCF. VP16, also referred to as Vmw65 and $\alpha$-TIF, is a multifunctional protein of 490 amino acids that serves as both an essential structural component of the HSV virion and an activator of HSV IE gene transcription (for reviews and references, see Thompson and McKnight 1992; O'Hare 1993|. It contains two functional regions: a potent 80 amino-acid carboxy-terminal transcriptional activation domain and a 400-amino-acid amino-terminal region, which negotiates assembly of the VP16-induced complex.

After HSV infection, VP16 first forms a heteromeric complex with HCF (Katan et al. 1990; Kristie and Sharp 1990; Xiao and Capone 1990; Stern and Herr 1991). HCF,

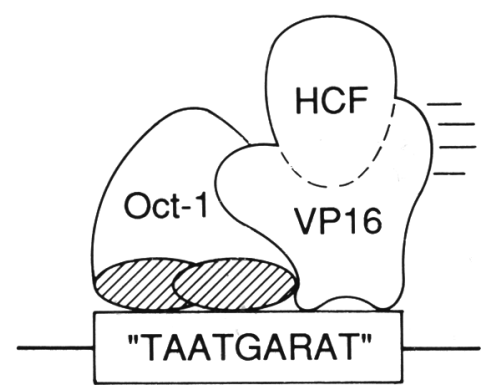

Figure 8. Diagram of the VPl6-induced complex. The box indicates the TAATGARAT DNA element, the hatched ovals indicate the Oct-1 POU $\mathrm{PO}_{\mathrm{S}}$ and $\mathrm{POU}_{\mathrm{H}}$ domains, and the four horizontal bars indicate the VP16 transcriptional activation domain. The broken border between VP16 and HCF denotes that these two proteins remain associated off the DNA. which has also been referred to as $\mathrm{Cl}$, VCAF, and CFF, is a large protein, which, after synthesis, is cleaved at one or more centrally located sites into heterogeneous amino- and carboxy-terminal halves that remain noncovalently associated with one another (Wilson et al. 1993; Kristie et al. 1995|. The cellular function of HCF is unknown, but its binding to VP16 promotes association of VP16 with Oct-1 on the target of VP16 activation, the $\left(\mathrm{OCTA}^{+}\right)$- and (OCTA $\left.^{-}\right)$TAATGARAT sites (see Fig. 6A) found in HSV IE promoters (Gerster and Roeder 1988; Kristie et al. 1989).

In the VP16-induced complex, VP16 apparently contacts each of the other components of the complex, Oct$1, \mathrm{HCF}$, and DNA, and mutations in VP16 can selectively affect each of these interactions /Stern and Herr 1991; Walker et al. 1994; J.-S. Lai and W. Herr, unpubl.). Although it is not universally accepted (Walker et al. 1994), a number of studies indicate that VP16 binds to DNA in the complex (Kristie and Sharp 1990; Stern and Herr 1991; C. Huang, J.-S. Lai, and W. Herr, unpubl.).

The influence of Oct-1 on VP16-induced complex formation differs depending on the nature of the Oct-1binding site (Cleary and Herr 1995). These differences are the result of the $\mathrm{POU}_{\mathrm{S}}$ domain. On an IOCTA $^{+}$|TAATGARAT site, the effect of mutations in the Oct-1 $\mathrm{POU}_{\mathrm{S}}$ domain on VP16-induced complex formation parallels their influence on DNA binding itself. On an (OCTA ${ }^{-}$ITAATGARAT site, however, where the $\mathrm{POU}_{\mathrm{S}}$ domain may interact with a GARAT element also bound by VP16, the effect of mutations in the $\mathrm{POU}_{\mathrm{S}}$ domain on formation of a VP16-induced complex does not always correspond to their effect on DNA binding to this site alone but, instead, appear to selectively affect VP16-induced complex formation. These different activities indicate that, by virtue of its ability to adopt different conformations on DNA, the POU domain can differentially influence association with a coregulatory protein on different sites.

VP16 associates well with Oct-1 but not Oct-2 by discriminating between the homeo domains of these two proteins (Stern et al. 1989). The Oct-1 and Oct-2 homeo domains differ at seven positions on the exposed surface of the DNA-bound homeo domain: three positions in each of $\alpha$-helices 1 and 2 and one position in the turn between $\alpha$-helices 2 and 3 (see Fig. 3), all of which are accessible when these proteins are bound to DNA. Although several residues in the Oct-1 homeo domain are important for association with VP16 (Pomerantz et al. 1992; Walker et al. 1994), one difference between the Oct- 1 and Oct- 2 homeo domains, a glutamic acid residue in Oct-1 for an alanine residue in Oct- 2 at the top of $\alpha$-helix 1 (position 22; see Fig. 3), is the primary determinant for selective association of Oct-1 and not Oct-2 with VP16 (Lai et al. 1992; Pomerantz et al. 1992). Exchange of this amino acid from Oct- 1 into Oct- 2 transfers the selective VP16 response of Oct-1 to Oct-2 (Lai et al. 1992). Thus, a single amino acid difference between two POU domains can have a large influence on the response to a coregulator, through its effects on coassociation. 
The adenovirus DNA polymerase also interacts with the Oct-1 homeo domain, but different residues are important for VP16 and adenovirus DNA polymerase association, demonstrating that different surfaces of the Oct-1 homeo domain can be responsible for interaction with heterologous proteins (Coenjaerts et al. 1994).

The VP16-induced complex provides a mechanism for selectivity in transcriptional regulation by proteins that bind the same DNA sequence

Although Oct-1 and Oct-2 share very similar POU domains (see Fig. 3) and both recognize the octamer sequence with high affinity, these two POU proteins display different transcriptional regulatory properties and thus have served as a paradigm for understanding how proteins with the same DNA-binding specificity can differentially activate transcription (for review, see Herr 1992). Oct- 1 is expressed in many if not all cell types and is implicated in regulating synthesis of proteins and RNAs that are required for cell growth and proliferation, such as histone $\mathrm{H} 2 \mathrm{~B}$, which is required for chromatin formation, and snRNAs, which are required for RNA processing. Oct- 2 expression is restricted to certain cell types, including B cells and neural cells, and is implicated in the regulation of immunoglobulin gene transcription.

Figure 9 illustrates how the selective association of VP16 with Oct-1 can result in differential regulation of transcription by Oct- 1 and Oct-2. As illustrated in Figure 9A, on high-affinity Oct-1- and Oct-2-binding sites (i.e., octamer sites), Oct-1 and Oct-2 preferentially activate different types of RNA polymerase II promoters: Oct-1 activates snRNA promoters preferentially, and Oct- 2 activates mRNA-type promoters preferentially. These different activities result from the different properties of "promoter-selective" activation domains that lie outside of the POU domains of these two proteins (Tanaka et al. 1992). Thus, promoter-selective activation domains provide one mechanism by which activators that share the same DNA-binding specificity can selectively activate different promoters.

Both Oct-1 and Oct-2, however, bind the IOCTA-|TAATGARAT site with low affinity in vitro (Fig. 9B) and do not activate either snRNA or mRNA promoters containing such a site effectively in vivo (Cleary et al. 1993). Oct-1, however, is stabilized on the (OCTA ${ }^{-}$|TAATGARAT site by its association with VP16 (see Fig. 9C) and can activate transcription of an mRNA-type promoter effectively via the potent VP16 activation domain; Oct- 2 still fails to activate transcription because it does not associate with VP16 (Cleary et al. 1993). Thus, by selective association with the Oct-1 POU domain, VP16 influences Oct-1 in two ways: It brings Oct-1 to a new regulatory site through corecruitment and provides a new activation domain that activates mRNA-type promoters very well. These two effects of VP16 on Oct-1 provide a second mechanism by which activators with the same DNA-binding specific-
A.

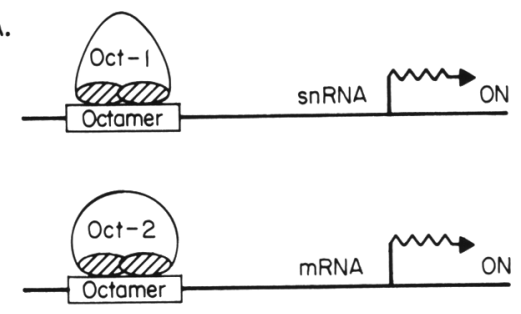

B.
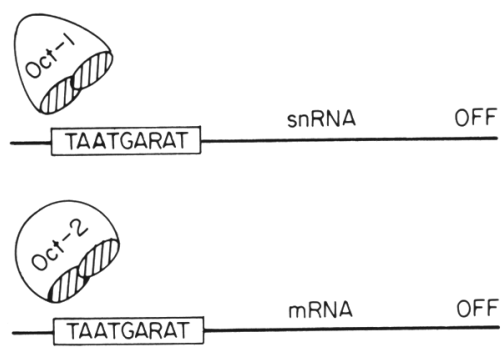

C.
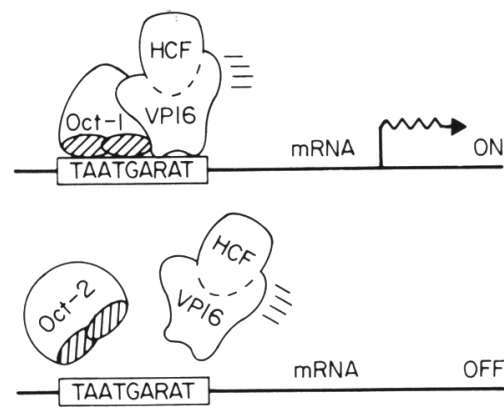

Figure 9. Differential regulation of transcription by Oct-1 and Oct-2 mediated by selective association of VP16 with Oct-1. $|A|$ Activation of an snRNA promoter by Oct-1 and an mRNA promoter by Oct- 2 from high-affinity octamer sites. $(B)$ Inactivity of Oct-1 and Oct-2 with promoters containing the low-affinity (OCTA - TAATGARAT site. (C) Activation of an mRNA promoter by Oct-1 but not Oct- 2 through selective corecruitment onto an OOCTA $^{-}$|TAATGARAT site with VP16 and HCF. The diagram of the Oct-1/VP16 complex is as described in Fig. 8.

ity, in this case Oct-1 and Oct-2, can differentially activate transcription.

\section{A B-cell-specific coregulator provides a mechanism for B-cell-specific activation of promoters by Oct-1}

Much in the way VP16 allows Oct-1 to activate mRNA promoters in HSV-infected cells, the B-cell-specific factor OCA-B (see Table 1) permits Oct-1 to activate mRNA promoters (i.e., immunoglobulin promoters) in B cells (Pierani et al. 1990; Luo et al. 1992; Gstaiger et al. 1995; Luo and Roeder 1995; Strubin et al. 1995). Unlike VP16, OCA-B associates with both the Oct- 1 and Oct-2 POU domains but not other POU domains. OCA-B enhances the ability of Oct-1 to activate immunoglobulin promot- 
ers, apparently by providing an mRNA-type activation domain (Luo et al. 1992; Gstaiger et al. 1995; Luo and Roeder 1995; Strubin et al. 1995). Thus, like VP16, OCA-B alters the promoter-selective activation domain properties of Oct-1 through association with the POU domain. This Oct-1-modifying activity probably explains why loss of Oct- 2 can be tolerated in B cells without complete loss of octamer-dependent B-cell-specific mRNA gene expression (Corcoran et al. 1993; Feldhaus et al. 1993; Pfisterer et al. 1994).

\section{A highly conserved DNA-binding structure confers transcriptional regulatory selectivity}

One of the surprises in the analysis of POU protein interaction with coregulators is that interaction with a highly conserved region, the POU domain itself, generates transcriptional regulatory selectivity. We originally imagined that regions of greater sequence difference, for example, sequences lying outside of the POU domain, would be the likely targets for selective interactions between POU proteins and coregulators. Subsequently, however, it became evident that only very subtle differences, as subtle as a single amino acid difference as in the case of the differential interaction of Oct-1 and Oct-2 with VP16, can provide POU-protein-coregulator selectivity. This finding may explain why the POU domain is an attractive target for coregulator interactions: It is sufficiently flexible to provide the very small changes required for selective interaction, and meanwhile, as a result of its function in DNA binding, it is a highly conserved structure that forms a solid foundation on which a coregulator can form protein-protein contacts.

\section{Versatile transcriptional regulation by a two-in-one DNA-binding domain}

In conclusion, the POU domain illustrates how the structure of a DNA-binding domain can profoundly influence the activity of transcriptional regulators. The POU domain represents a fused heterodimer in which two different types of structurally independent $\mathrm{HTH}$ containing DNA-binding domains are brought together to form a single DNA-binding unit. The flexibility of the association of the two domains, provided by a linker with little apparent structure, results in versatility in its interactions with DNA and other proteins in transcriptional regulation.

\section{Acknowledgments}

We thank Rajeev Aurora for his initiative in the eventual determination of the Oct-1 POU-domain structure; T. Bürglin and G. Ruvkun, Y. Luo and R. Roeder, and V. Mittal and N. Hernandez for communicating results prior to publication; our colleagues, C. Huang and J.-S. Lai, for contributing unpublished results referred to in the text; J. Duffy and J. Reader for help in preparing the figures and manuscript, respectively; A. Doseff, N. Hernandez, M. Tanaka, G. Ruvkun, C. Sadowski, and W. Tansey for critical readings of the manuscript; and $J$. Cuddihy and $T$. Grodzicker for encouragement.

\section{References}

Alber, T. 1992. Structure of the leucine zipper. Curr. Opin. Genet. Dev. 2: 205-210.

Andersen, B., M.D. Schonemann, S.E. Flynn, R.V. Pearse II, H. Singh, and M.G. Rosenfeld. 1993a. Skn-la and Skn-li: Two functionally distinct Oct-2-related factors expressed in epidermis. Science 260: 78-82.

Andersen, B., M.D. Schonemann, R.V. Pearse II, K. Jenne, J. Sugarman, and M.G. Rosenfeld. 1993b. Brn-5 is a divergent POU domain factor highly expressed in layer IV of the neocortex. J. Biol. Chem. 268: 23390-23398.

Anderson, M.G., G.L. Perkins, P. Chittick, R.J. Shrigley, and W.A. Johnson. 1995. drifter, a Drosophila POU-domain transcription factor, is required for correct differentiation and migration of tracheal cells and midline glia. Genes \& Dev. 9: 123-137.

apRhys, C.M.J., D.M. Ciufo, E.A. O’Neill, T.J. Kelly, and G.S. Hayward. 1989. Overlapping octamer and TAATGARAT motifs in the VF65-response elements in herpes simplex virus immediate-early promoters represent independent binding sites for cellular Nuclear Factor III. J. Virol. 63: 27982812.

Assa-Munt, N., R.J. Mortishire-Smith, R. Aurora, W. Herr, and P.E. Wright. 1993. The solution structure of the Oct-1 POUspecific domain reveals a striking similarity to the bacteriophage $\lambda$ repressor DNA-binding domain. Cell 73: 193205.

Aurora, R. and W. Herr. 1992. Segments of the POU domain influence one another's DNA-binding specificity. Mol. Cell. Biol. 12: 455-467.

Baumruker, T., R. Sturm, and W. Herr. 1988. OBP100 binds remarkably degenerate octamer motifs through specific interactions with flanking sequences. Genes \& Dev. 2: 14001413.

Bendall, A.J., R.A. Sturm, P.A.C. Danoy, and P.L. Molloy. 1993. Broad binding-site specificity and affinity properties of octamer $l$ and brain octamer-binding proteins. Eur. J. Biochem. 217: 799-811.

Bhat, K.M. and P. Schedl. 1994. The Drosophila miti-mere gene, a member of the POU family, is required for the specification of the RP2/sibling lineage during neurogenesis. Development 120: 1483-1501.

Billin, A.N., K.A. Cockerill, and S.J. Poole. 1991. Isolation of a family of Drosophila POU domain genes expressed in early development. Mech. Dev. 34: 75-84.

Bodner, M. and M. Karin. 1987. A pituitary-specific trans-acting factor can stimulate transcription from the growth hormone promoter in extracts of nonexpressing cells. Cell 50: 267275.

Bodner, M., J.-L. Castrillo, L.E. Theill, T. Deerinck, M. Ellisman, and M. Karin. 1988. The pituitary-specific transcription factor GHF-1 is a homeobox-containing protein. Cell 55: $505-518$

Botfield, M.C., A. Jancso, and M.A. Weiss. 1992. Biochemical characterization of the Oct-2 POU domain with implications for bipartite DNA recognition. Biochemistry 31: 58415848 .

- 1994. Mapping critical residues in eukaryotic DNAbinding proteins: A plasmid-based genetic selection strategy with application to the Oct-2 POU motif. Biochemistry 33: 6177-6185

Brüggemeier, U., M. Kalff, S. Franke, C. Scheidereit, and M. Beato. 1991. Ubiquitous transcription factor OTF-1 mediates induction of the MMTV promoter through synergistic interaction with hormone receptors. Cell 64: 565-572. 
Bürglin, T.R. 1994. A comprehensive classification of homeobox genes. In Guidebook to the homeobox genes (ed. D. Duboulel, pp. 27-71. Oxford University Press, Oxford, UK.

Bürglin, T.R., M. Finney, A. Coulson, and G. Ruvkun. 1989. Caenorhabditis elegans has scores of homeobox-containing genes. Nature 341: 239-243.

Cleary, M.A. and W. Herr. 1995. Mechanisms for flexibility in DNA sequence recognition and VP16-induced complex formation by the Oct-1 POU domain. Mol. Cell. Biol. 15: 2090 2100.

Cleary, M.A., S. Stern, M. Tanaka, and W. Herr. 1993. Differential positive control by Oct- 1 and Oct-2: Activation of a transcriptionally silent motif through Oct- 1 and VP16 corecruitment. Genes \& Dev. 7: 72-83.

Clerc, R.G., L.M. Corcoran, J.H. LeBowitz, D. Baltimore, and P.A. Sharp. 1988. The B-cell-specific Oct-2 protein contains POU box- and homeo box-type domains. Genes \& Dev. 2: $1570-1581$.

Coenjaerts, F.E.J., J.A.W.M. van Oosterhout, and P.C. van der Vliet. 1994. The Oct-1 POU domain stimulates adenovirus DNA replication by a direct interaction between the viral precursor terminal protein-DNA polymerase complex and the POU homeodomain. EMBO I. 13: 5401-5409.

Corcoran, L.M., M. Karvelas, G.J.V. Nossal, Z.-S. Ye, T. Jacks, and D. Baltimore. 1993. Oct-2, although not required for early B-cell development, is critical for later B-cell maturation and for postnatal survival. Genes \& Dev. 7: 570-582.

Day, R.N. and K.H. Day. 1994. An alternatively spliced form of Pit-l represses prolactin gene expression. Mol. Endocrinol. 8: $374-381$.

Dekker, N., M. Cox, R. Boelens, C. Verrijzer, P.C. van der Vliet, and R. Kaptein. 1993. Solution structure of the POU-specific DNA-binding domain of Oct-1. Nature 362: 852-855.

Elsholtz, H.P., V.R. Albert, M.N. Treacy, and M.G. Rosenfeld. 1990. A two-base change in a POU factor-binding site switches pituitary-specific to lymphoid-specific gene expression. Genes \& Dev. 4: 43-51.

Falkner, F.G. and H.G. Zachau. 1984. Correct transcription of an immunoglobulin $\kappa$ gene requires an upstream fragment containing conserved sequence elements. Nature 310: 7174.

Feldhaus, A.L., C.A. Klug, K.L. Arvin, and H. Singh. 1993. Targeted disruption of the Oct-2 locus in a B cell provides genetic evidence for two distinct cell type-specific pathways of octamer element-mediated gene activation. EMBO $J$. 12: $2763-2772$.

Finney, M., G. Ruvkun, and H.R. Horvitz. 1988. The C. elegans cell lineage and differentiation gene unc- 86 encodes a protein with a homeodomain and extended similarity to transcription factors. Cell 55: 757-769.

Gerrero, M.R., R.J. McEvilly, E. Turner, C.R. Lin, S. O'Connell, K.J. Jenne, M.V. Hobbs, and M.G. Rosenfeld. 1993. Brn-3.0: A POU-domain protein expressed in the sensory, immune, and endocrine systems that functions on elements distinct from known octamer motifs. Proc. Natl. Acad. Sci. 90: 1084110845.

Gerster, T. and R.G. Roeder. 1988. A herpesvirus trans-activating protein interacts with transcription factor OTF-1 and other cellular proteins. Proc. Natl. Acad. Sci. 85: 6347-6351.

Greenstein, D., S. Hird, R.H.A. Plasterk, Y. Andachi, Y. Kohara, B. Wang, M. Finney, and G. Ruvkun. 1994. Targeted mutations in the Caenorhabditis elegans POU homeo box gene ceh-18 cause defects in oocyte cell cycle arrest, gonad migration, and epidermal differentiation. Genes \& Dev. 8: 1935-1948.

Gstaiger, M., L. Knoepfel, O. Georgiev, W. Schaffner, and C.M.
Hovens. 1995. A B-cell coactivator of octamer-binding transcription factors. Nature 373: 360-362.

Guarente, L., J.S. Nye, A. Hochschild, and M. Ptashne. 1982. Mutant $\lambda$ phage repressor with a specific defect in its positive control function. Proc. Natl. Acad. Sci. 79: 2236-2239.

Hanes, S.D. and R. Brent. 1989. DNA specificity of the bicoid activator protein is determined by homeodomain recognition helix residue 9. Cell 57: 1275-1283.

Hara, Y., A.C. Rovescalli, Y. Kim, and M. Nirenberg. 1992. Structure and evolution of four POU domain genes expressed in mouse brain. Proc. Natl. Acad. Sci. 89: 32803284.

Hawley, D.K. and W.R. McClure. 1983. The effect of a lambda repressor mutation on the activation of transcription initiation from the lambda $P_{R M}$ promoter. Cell 32: 327-333.

He, X., M.N. Treacy, D.M. Simmons, H.A. Ingraham, L.W. Swanson, and M.G. Rosenfeld. 1989. Expression of a large family of POU-domain regulatory genes in mammalian brain development. Nature 340: 35-42.

Henry, R.W., C.L. Sadowski, R. Kobayashi, and N. Hernandez. 1995. A TBP-TAF complex required for transcription of human snRNA genes by RNA polymerases II and III. Nature 374: 653-656.

Herr, W. 1992. Oct-1 and Oct-2: Differential transcriptional regulation by proteins that bind to the same DNA sequence. In Transcriptional regulation (ed. S. McKnight and K. Yamamotol, pp. 1103-1135. Cold Spring Harbor Laboratory Press, Cold Spring Harbor, New York.

Herr, W., R.A. Sturm, R.G. Clerc, L.M. Corcoran, D. Baltimore, P.A. Sharp, H.A. Ingraham, M.G. Rosenfeld, M. Finney, G. Ruvkun, and H.R. Horvitz. 1988. The POU domain: A large conserved region in the mammalian pit-1, oct-1, oct-2, and Caenorhabditis elegans unc-86 gene products. Genes \& Dev. 2: 1513-1516.

Hinkley, C.S., J.F. Martin, D. Leibham, and M. Perry. 1992. Sequential expression of multiple POU proteins during amphibian early development. Mol. Cell. Biol. 12: 638-649.

Hochschild, A., N. Irwin, and M. Ptashne. 1983. Repressor structure and the mechanism of positive control. Cell 32: 319-325.

Ingraham, H.A., R. Chen, H.J. Mangalam, H.P. Elsholtz, S.E. Flynn, C.R. Lin, D.M. Simmons, L. Swanson, and M.G. Rosenfeld. 1988. A tissue-specific transcription factor containing a homeodomain specifies a pituitary phenotype. Cell 55: 519-529.

Ingraham, H.A., S.E. Flynn, J.W. Voss, V.R. Albert, M.S. Kapiloff, L. Wilson, and M.G. Rosenfeld. 1990. The POU-specific domain of Pit-1 is essential for sequence-specific, high affinity DNA binding and DNA-dependent Pit-1-Pit-1 interactions. Cell 61: 1021-1033.

Jancso, A., M.C. Botfield, L.C. Sowers, and M.A. Weiss. 1994. An altered-specificity mutation in a human POU domain demonstrates functional analogy between the POU-specific subdomain and phage $\lambda$ repressor. Proc. Natl. Acad. Sci. 91: 3887-3891.

Janson, L. and U. Pettersson. 1990. Cooperative interactions between transcription factors Spl and OTF-1. Proc. Natl. Acad. Sci. 87: 4732-4736.

Johnson, W.A. and J. Hirsh. 1990. Binding of a Drosophila POUdomain protein to a sequence element regulating gene expression in specific dopaminergic neurons. Nature 343: 467470.

Kapiloff, M.S., Y. Farkash, M. Wegner, and M.G. Rosenfeld. 1991. Variable effects of phosphorylation of Pit-1 dictated by the DNA response elements. Science 253: 786-789.

Katan, M., A. Haigh, C.P. Verrijzer, P.C. van der Vliet, and P. 
O'Hare. 1990. Characterization of a cellular factor which interacts functionally with Oct-1 in the assembly of a multicomponent transcription complex. Nucleic Acids Res. 18: $6871-6880$.

Kemler, I., E. Schreiber, M.M. Müller, P. Matthias, and W. Schaffner. 1989. Octamer transcription factors bind to two different sequence motifs of the immunoglobulin heavy chain promoter. EMBO J. 8: 2001-2008.

Kissinger, C.R., B. Liu, E. Martin-Blanco, T.B. Kornberg, and C.O. Pabo. 1990. Crystal structure of an engrailed homeodomain-DNA complex at $2.8 \AA$ resolution: A framework for understanding homeodomain-DNA interactions. Cell 63: $579-590$.

Klemm, J.D., M.A. Rould, R. Aurora, W. Herr, and C.O. Pabo. 1994. Crystal structure of the Oct-1 POU domain bound to an octamer site: DNA recognition with tethered DNA-binding modules. Cell 77: 21-32.

Kristie, T.M. and P.A. Sharp. 1990. Interactions of the Oct-1 POU subdomains with specific DNA sequences and the HSV $\alpha$-trans-activator protein. Genes \& Dev. 4: 2383-2396.

Kristie, T.M., J.H. LeBowitz, and P.A. Sharp. 1989. The octamerbinding proteins form multi-protein-DNA complexes with the HSV $\alpha$-TIF regulatory protein. EMBO I. 8: 4229-4238.

Kristie, T.M., J.L. Pomerantz, T.C. Twomey, S.A. Parent, and P.A. Sharp. 1995. The cellular $\mathrm{Cl}$ factor of the herpes simplex virus enhancer complex is a family of polypeptides. I. Biol. Chem. 270: 4387-4394.

Lai, J.-S., M.A. Cleary, and W. Herr. 1992. A single amino acid exchange transfers VP16-induced positive control from the Oct-1 to the Oct- 2 homeo domain. Genes \& Dev. 6: 20582065.

Landolfi, N.F., J.D. Capra, and P.W. Tucker. 1986. Interaction of cell-type-specific nuclear proteins with immunoglobulin $\mathrm{V}_{\mathrm{H}}$ promoter region sequences. Nature 323: 548-551.

Laughon, A. and M.P. Scott. 1984. Sequence of a Drosophila segmentation gene: Protein structure homology with DNAbinding proteins. Nature 310: 25-31.

LeBowitz, J.H., R.G. Clerc, M. Brenowitz, and P.A. Sharp. 1989. The Oct-2 protein binds cooperatively to adjacent octamer sites. Genes \& Dev. 3: 1625-1638.

Lenardo, M.J., L. Staudt, P. Robbins, A. Kuang, R.C. Mulligan, and D. Baltimore. 1989. Repression of the IgH enhancer in teratocarcinoma cells associated with a novel octamer factor. Science 243: 544-546.

Li, M., H. Moyle, and M.M. Susskind. 1994. Target of the transcriptional activation function of phage $\lambda$ cI protein. Science 263: $75-77$.

Li, P., X. He, M.R. Gerrero, M. Mok, A. Aggarwal, and M.G. Rosenfeld. 1993. Spacing and orientation of bipartite DNAbinding motifs as potential functional determinants for POU domain factors. Genes \& Dev. 7: 2483-2496.

Lloyd, A. and S. Sakonju. 1991. Characterization of two Drosophila POU domain genes, related to oct- 1 and oct-2, and the regulation of their expression patterns. Mech. Dev. 36: 87102.

Luo, Y. and R.G. Roeder. 1995. Cloning, functional characterization and mechanism of action of the B cell-specific transcriptional coactivator OCA-B. Mol. Cell. Biol. (in press).

Luo, Y., H. Fujii, T. Gerster, and R.G. Roeder. 1992. A novel B cell-derived coactivator potentiates the activation of immunoglobulin promoters by octamer-binding transcription factors. Cell 71: 231-241.

Monuki, E.S., G. Weinmaster, R. Kuhn, and G. Lemke. 1989. SCIP: A glial POU domain gene regulated by cyclic AMP. Neuron 3: 783-793.

Müller, M.M., S. Ruppert, W. Schaffner, and P. Matthias. 1988.
A cloned octamer transcription factor stimulates transcription from lymphoid-specific promoters in non-B cells. $\mathrm{Na}$ ture 336: 544-551.

Murphy, S., J.-B. Yoon, T. Gerster, and R.G. Roeder. 1992. Oct-1 and Oct- 2 potentiate functional interactions of a transcription factor with the proximal sequence element of small nuclear RNA genes. Mol. Cell. Biol. 12: 3247-3261.

Nelson, C., V.R. Albert, H.P. Elsholtz, L.I.-W. Lu, and M.G. Rosenfeld. 1988. Activation of cell-specific expression of rat growth hormone and prolactin genes by a common transcription factor. Science 239: 1400-1405.

O'Hare, P. 1993. The virion transactivator of herpes simplex virus. In The Alpha-Herpesviruses (ed. A.J. Davison), pp 145-155. Saunders Scientific Publications, Philadelphia, PA.

Okamoto, K., H. Okazawa, A. Okuda, M. Sakai, M. Muramatsu, and H. Hamada. 1990. A novel octamer binding transcription factor is differentially expressed in mouse embryonic cells. Cell 60: 461-472.

Otting, G., Y.Q. Qian, M. Billeter, M. Müller, M. Affolter, W.J. Gehring, and K. Wüthrich. 1990. Protein-DNA contacts in the structure of a homeodomain-DNA complex determined by nuclear magnetic resonance spectroscopy in solution. EMBO I. 9: 3085-3092.

Pabo, C.O. and R.T. Sauer. 1992. Transcription factors: Structural families and principles of DNA recognition. Annu. Rev. Biochem. 61: 1053-1095.

Pabo, C.O., A.K. Aggarwal, S.R. Jordan, L.J. Beamer, U.R. Obeysekare, and S.C. Harrison. 1990. Conserved residues make similar contacts in two repressor-operator complexes. Science 247: 1210-1213.

Parslow, T.G., D.L. Blair, W.J. Murphy, and D.K. Granner. 1984. Structure of the 5' ends of immunoglobulin genes: A novel conserved sequence. Proc. Natl. Acad. Sci. 81: 26502654.

Pfäffle, R.W., G.E. DiMattia, J.S. Parks, M.R. Brown, J.M. Wit, M. Jansen, H. Van der Nat, J.L. Van den Brande, M.G. Rosenfeld, and H.A. Ingraham. 1992. Mutation of the POU-specific domain of Pit-1 and hypopituitarism without pituitary hypoplasia. Science 257: 1118-1121.

Pfisterer, P., A. Annweiler, C. Ullmer, L.M. Corcoran, and T. Wirth. 1994. Differential transactivation potential of Oct 1 and Oct 2 is determined by additional $B$ cell-specific activities. EMBO I. 13: 1654-1663.

Pierani, A., A. Heguy, H. Fujii, and R.G. Roeder. 1990. Activation of octamer-containing promoters by either octamerbinding transcription factor 1 (OTF-1) or OTF- 2 and requirement of an additional B-cell-specific component for optimal transcription of immunoglobulin promoters. Mol. Cell. Biol. 10: 6204-6215.

Poellinger, L., B.K. Yoza, and R.G. Roeder. 1989. Functional cooperativity between protein molecules bound at two distinct sequence elements of the immunoglobulin heavychain promoter. Nature 337: 573-576.

Pomerantz, J.L. and P.A. Sharp. 1994. Homeodomain determinants of major groove recognition. Biochemistry 33: 1085110858.

Pomerantz, J.L., T.M. Kristie, and P.A. Sharp. 1992. Recognition of the surface of a homeo domain protein. Genes \& Dev. 6: 2047-2057.

Rosenfeld, M.G. 1991. POU-domain transcription factors: pouer-ful developmental regulators. Genes \& Dev. 5: 897-907.

Rosner, M.H., M.A. Vigano, K. Ozato, P.M. Timmons, F. Poirier, P.W.J. Rigby, and L.M. Staudt. 1990. A POU-domain transcription factor in early stem cells and germ cells of the mammalian embryo. Nature 345: 686-692.

Ruvkun, G. and M. Finney. 1991. Regulation of transcription 
and cell identity by POU domain proteins. Cell 64: 475-478. Sadowski, C.L., R.W. Henry, S.M. Lobo, and N. Hernandez. 1993. Targeting TBP to a non-TATA box cis-regulatory element: A TBP-containing complex activates transcription from snRNA promoters through the PSE. Genes \& Dev. 7: 1535-1548.

Scheidereit, C., J.A. Cromlish, T. Gerster, K. Kawakami, C.-G. Balmaceda, R.A. Currie, and R.G. Roeder. 1988. A human lymphoid-specific transcription factor that activates immunoglobulin genes is a homeobox protein. Nature 336: 551557.

Schöler, H.R., A.K. Hatzopoulos, R. Balling, N. Suzuki, and P. Gruss. 1989. A family of octamer-specific proteins present during mouse embryogenesis: Evidence for germline-specific expression of an Oct factor. EMBO I. 8: 2543-2550.

Schöler, H.R., S. Ruppert, N. Suzuki, K. Chowdhury, and P. Gruss. 1990. New type of POU domain in germ line-specific protein Oct-4. Nature 344: 435-439.

Schöler, H.R., T. Ciesiolka, and P. Gruss. 1991. A nexus between Oct-4 and E1A: Implications for gene regulation in embryonic stem cells. Cell 66: 291-304.

Schreiber, E., K. Harshman, I. Kemler, U. Malipiero, W. Schaffner, and A. Fontana. 1990. Astrocytes and glioblastoma cells express novel octamer-DNA binding proteins distinct from the ubiquitous Oct- 1 and B cell type Oct- 2 proteins. Nucleic Acids Res. 18: 5495-5503.

Segil, N., S.B. Roberts, and N. Heintz. 1991. Mitotic phosphorylation of the Oct-1 homeodomain and regulation of Oct-1 DNA binding activity. Science 254: 1814-1816.

Shepherd, J.C.W., W. McGinnis, A.E. Carrasco, E.M. De Robertis, and W.J. Gehring. 1984. Fly and frog homoeo domains show homologies with yeast mating type regulatory proteins. Nature 310: 70-71.

Singh, H., R. Sen, D. Baltimore, and P.A. Sharp. 1986. A nuclear factor that binds to a conserved sequence motif in transcriptional control elements of immunoglobulin genes. Nature 319: 154-158.

Sivaraja, M., M.C. Botfield, M. Mueller, A. Jancso, and M.A. Weiss. 1994. Solution structure of a POU-specific homeodomain: 3D-NMR studies of human B-cell transcription factor Oct-2. Biochemistry 33: 9845-9855.

Staudt, L.M., H. Singh, R. Sen, T. Wirth, P.A. Sharp, and D. Baltimore. 1986. A lymphoid-specific protein binding to the octamer motif of immunoglobulin genes. Nature 323: 640643.

Stern, S. and W. Herr. 1991. The herpes simplex virus transactivator VP16 recognizes the Oct-1 homeo domain: Evidence for a homeo domain recognition subdomain. Genes \& Dev. 5: 2555-2566.

Stern, S., M. Tanaka, and W. Herr. 1989. The Oct-1 homoeodomain directs formation of a multiprotein-DNA complex with the HSV transactivator VP16. Nature 341: 624-630.

Strubin, M., J.W. Newell, and P. Matthias. 1995. OBF-1, a novel $B$ cell-specific coactivator that stimulates immunoglobulin promoter activity through association with octamer-binding proteins. Cell 80: 497-506.

Sturm, R.A. and W. Herr. 1988. The POU domain is a bipartite DNA-binding structure. Nature 336: 601-604.

Sturm, R.A., G. Das, and W. Herr. 1988. The ubiquitous octamer-binding protein Oct-1 contains a POU domain with a homeo box subdomain. Genes \& Dev. 2: 1582-1599.

Takeda, H., T. Matsuzaki, T. Oki, T. Miyagawa, and H. Amanuma. 1994. A novel POU domain gene, zebrafish pou2: Expression and roles of two alternatively spliced twin products in early development. Genes \& Dev. 8: 45-59.

Tanaka, M., J.-S. Lai, and W. Herr. 1992. Promoter-selective activation domains in Oct- 1 and Oct- 2 direct differential activation of an snRNA and mRNA promoter. Cell 68: 755767.

Theil, T., S. McLean-Hunter, M. Zörnig, and T. Möröy. 1993. Mouse $B R N-3$ family of POU transcription factors: A new aminoterminal domain is crucial for the oncogenic activity of BRN-3A. Nucleic Acids Res. 21: 5921-5929.

Thompson, C.C. and S.L. McKnight. 1992. Anatomy of an enhancer. Trends Genet. 8: 232-236.

Treacy, M.N., L.I. Neilson, E.E. Turner, X. He, and M.G. Rosenfeld. 1992. Twin of I-POU: A two amino acid difference in the I-POU homeodomain distinguishes an activator from an inhibitor of transcription. Cell 68: 491-505.

Treisman, J., P. Gönczy, M. Vashishtha, E. Harris, and C. Desplan. 1989. A single amino acid can determine the DNA binding specificity of homeodomain proteins. Cell 59: 553562.

Ullman, K.S., W.M. Flanagan, C.A. Edwards, and G.R. Crabtree. 1991. Activation of early gene expression in T lymphocytes by Oct- 1 and an inducible protein, $\mathrm{OAP}^{40}$. Science 254: 558562.

Ullman, K.S., J.P. Northrop, A. Admon, and G.R. Crabtree. 1993. Jun family members are controlled by a calcium-regulated, cyclosporin A-sensitive signaling pathway in activated T lymphocytes. Genes \& Dev. 7: 188-196.

Verrijzer, C.P. and P.C. van der Vliet. 1993. POU domain transcription factors. Biochim. Biophys. Acta 1173: 1-21.

Verrijzer, C.P., A.J. Kal, and P.C. van der Vliet. 1990. The oct-1 homeo domain contacts only part of the octamer sequence and full oct-1 DNA-binding activity requires the POU-specific domain. Genes \& Dev. 4: 1964-1974.

Verrijzer, C.P., M.J. Alkema, W.W. van Weperen, H.C. Van Leeuwen, M.J.J. Strating, and P.C. van der Vliet. 1992. The DNA binding specificity of the bipartite POU domain and its subdomains. EMBO I. 11: 4993-5003.

Voss, J.W., L. Wilson, and M.G. Rosenfeld. 1991. POU-domain proteins Pit-1 and Oct-1 interact to form a heteromeric complex and can cooperate to induce expression of the prolactin promoter. Genes \& Dev. 5: 1309-1320.

Walker, S., S. Hayes, and P. O'Hare. 1994. Site-specific conformational alteration of the Oct-1 POU domain-DNA complex as the basis for differential recognition by Vmw65 (VP16). Cell 79: 841-852.

Wharton, R.P. and M. Ptashne. 1987. A new-specificity mutant of 434 repressor that defines an amino acid-base pair contact. Nature 326: 888-891.

Wilson, A.C., K. LaMarco, M.G. Peterson, and W. Herr 1993. The VP16 accessory protein HCF is a family of polypeptides processed from a large precursor protein. Cell 74: 115-125.

Xiao, P. and J.P. Capone. 1990. A cellular factor binds to the herpes simplex virus type 1 trans-activator $\operatorname{Vmw} 65$ and is required for Vmw65-dependent protein-DNA complex assembly with Oct-1. Mol. Cell. Biol. 10: 4974-4977.

Xue, D., Y. Tu, and M. Chalfie. 1993. Cooperative interactions between the Caenorhabditis elegans homeoproteins UNC86 and MEC-3. Science 261: 1324-1328.

Yoon, J.-B., S. Murphy, L. Bai, Z. Wang, and R.G. Roeder. 1995. Proximal sequence element-binding transcription factor (PTF) is a multisubunit complex required for transcription of both RNA polymerase II- and RNA polymerase III-dependent small nuclear RNA genes. Mol. Cell. Biol. 15: 20192027.

Zwilling, S., A. Annweiler, and T. Wirth. 1994. The POU domains of the Oct 1 and Oct 2 transcription factors mediate specific interaction with TBP. Nucleic Acids Res. 22: 16551662. 


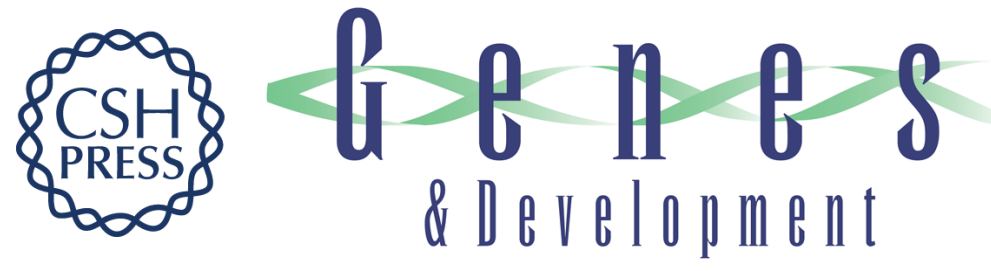

\section{The POU domain: versatility in transcriptional regulation by a flexible two-in-one DNA-binding domain.}

W Herr and M A Cleary

Genes Dev. 1995, 9:

Access the most recent version at doi:10.1101/gad.9.14.1679

References This article cites 116 articles, 49 of which can be accessed free at: http://genesdev.cshlp.org/content/9/14/1679.full.html\#ref-list-1

License

Email Alerting

Service

Receive free email alerts when new articles cite this article - sign up in the box at the top right corner of the article or click here.

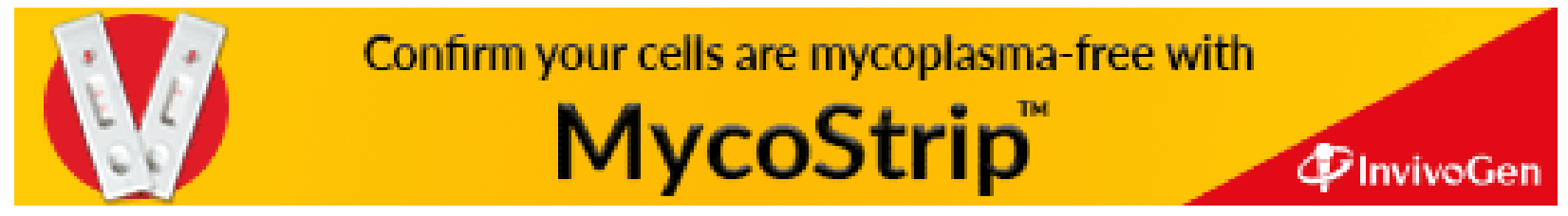

